\title{
High Temperature Solid Oxide Fuel Cell Generator Development
}

DOE Cooperative Agreement No. DE-FC26-97FT34139

Final Technical Progress Report

Revision 1

Reporting Period:

August, 1997 - September, 2007

\section{Prepared for}

National Energy Technology Laboratory

U.S. Department of Energy

3610 Collins Ferry Road

P. O. Box 880

Morgantown, WV 26507-0880

by

Siemens Power Generation

Stationary Fuel Cells

George Westinghouse Science and Technology Center

1310 Beulah Road

Pittsburgh, PA 15235-5098

Program Manager: Joseph F. Pierre

July, 2008 


\section{DISCLAIMER}

This report was prepared as an account of work sponsored by an agency of the United States Government. Neither the United States Government nor any agency thereof, nor any of their employees, make any warranty, expressed or implied, or assumed any legal liability or responsibility for the accuracy, completeness, or usefulness of any information, apparatus, product, or process disclosed, or represents that its use would not infringe privately owned rights. Reference herein to any specific commercial product, process, or service by trade name, trademark, manufacturer, or otherwise does not necessarily constitute or imply its endorsement, recommendation, or favoring by the United States Government or any agency thereof. The views and opinions of authors expressed herein do not necessarily state or reflect those of the United States Government or any agency thereof. 


\section{ABSTRACT}

This report describes the results of the tubular SOFC development program from August 22, 1997 to September 30, 2007 under the Siemens/U.S. Department of Energy Cooperative Agreement. The technical areas discussed include cell manufacturing development, cell power enhancement, SOFC module and system cost reduction and technology advancement, and our field unit test program. Whereas significant progress has been made toward commercialization, significant effort remains to achieve our cost, performance and reliability targets for successful commercialization. 


\section{TABLE OF CONTENTS}

\begin{tabular}{|c|c|}
\hline 1.0 & Introduction \\
\hline .0 & Cell Manufacturing Development (Task 1). \\
\hline .0 & Cell Technology Development (Task 2) .. \\
\hline 0 & Module Cost Reduction and Technology Development (Tasks 3 and 4).. \\
\hline & System Cost Reduction and Technology Development (Task 5) ................... \\
\hline & Automated Manufacturing Facility (Task 6 )....... \\
\hline & EDB/ELSAM 100 kWe Power System Field Test (Task 7).. \\
\hline & m Field Tests (Task 8) ... \\
\hline & ask 9) ..... \\
\hline & \\
\hline & commendations for Future Work \\
\hline
\end{tabular}

\section{LIST OF FIGURES}

Figure 2-1 Comparison of 1997 Tubular SOFC Manufacturing Process with

2007 Manufacturing Process

Figure 3-1 Cross Sections of Cylindrical, HPD5-R1 and Delta8 Cells ................................... 14

Figure 4-1 Measured Cell Voltage vs. Current Density at Various Pressures ........................ 17

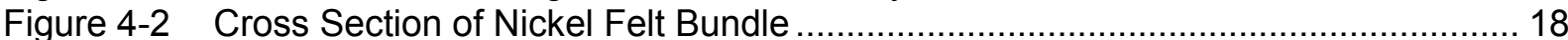

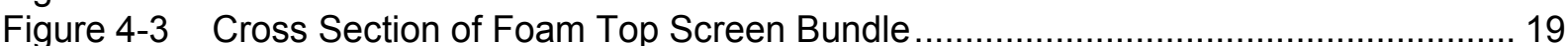

Figure 6-1 Photograph of Building Intended for Automated Manufacturing Facility ................ 25

Figure 7-1 Photograph of the EDB/ELSAM 100 kWe Power System ................................... 26

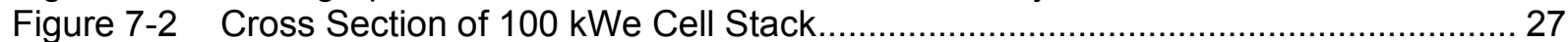

Figure 7-3 Fuel Side Flow Paths within the 100 kWe Generator ........................................ 27

Figure 8-1a CHP System Simplified Flow Schematic ........................................................ 30

Figure 8-1b PH System Simplified Flow Schematic ............................................................ 30

Figure 8-2 PH-220 Simplified Process Flow Diagram ......................................................... 31

Figure 8-3 Photograph of the SCE PH-220 Power System ............................................... 32

Figure 8-4 Isometric Drawing of the SCE PH-220 Power System ....................................... 32

Figure 8-5 Photograph of the OPG CHP-250 Power System ........................................... 35

Figure 8-6 Photograph of the RWE PH-300 Power System.............................................. 37

Figure 8-7 Photograph of the Stadtwerke Hannover CHP-125 Power System ...................... 39

Figure 9-1 CHP-125 Predicted Power System Cost vs. Cumulative Volume .......................... 43

\section{LIST OF TABLES}

Table 3-1 Performance Comparison of Various Cell Designs.............................................. 15

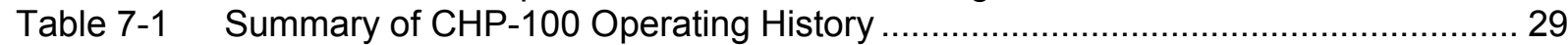

Table 8-1 Summary of PH-220 Operating History .......................................................... 34

Table 9-1 Summary of CHP-250 Due Diligence Cost Study ............................................. 42 


\section{EXECUTIVE SUMMARY}

This report describes the technical progress made toward tubular SOFC commercialization over the time period August 1997 through September 2007 under the U.S. DOE Cooperative Agreement. The state-of-the-art in tubular SOFC technology at the start of the 10 year Cooperative Agreement was the EDB/ELSAM (a consortium of Dutch and Danish utilities) $100 \mathrm{kWe}$ Combined Heat and Power (CHP) System. The 1152 cells were $150 \mathrm{~cm}$ active length, air electrode supported, tubular SOFCs. The interconnection was applied by an Atmospheric Plasma Spray (APS) process. The electrolyte and fuel electrode were applied by a very expensive process called Electrochemical Vapor Deposition (EVD). The air electrode support tubes were manufactured by our supplier at the time, NGK of Japan, at a price of $\$ 1,200$ per tube. This price corresponded to $\$ 25,000$ per $\mathrm{kWe}$ with a $50 \%$ yield starting from interconnection deposition to finished cell. The SOFC module contained a number of innovative design features, such as stack reformers and recirculation of depleted fuel, but nearly all the module components were made from expensive materials, such as Inconel 600, all-alumina fiber board and dense alumina. The balance-of-plant (BOP) also contained expensive, high temperature $\left(\leq 850^{\circ} \mathrm{C}\right)$ components, such as the air/exhaust recuperator, startup heater, and air/exhaust piping, but the most expensive component in the BOP was the Power Conditioning System (PCS) costing $\$ 1,000$ per kWe. The unit's direct factory cost was about $\$ 65,000$ per kWe $(\$ 35,000$ per kWe for cells, $\$ 20,000$ per kWe for the module and $\$ 10,000$ per kWe for the BOP), a factor of 15 to 20 higher than the commercial market entry cost target. Power system testing started in October 1997 at the beginning of the Cooperative Agreement and the unit performed very well as discussed below.

The focus of the 10 year Cooperative Agreement was cell manufacturing cost reduction, cell power enhancement, module (including bundling) cost reduction, advanced power systems development (pressurized hybrid systems and "zero emissions" system), BOP cost reduction, and demonstrating these technology advancements in customer operated field unit tests. Cell testing (1, 2 or 4 cells per test article) provided development support and performance feedback for cell and bundle design innovations, and manufacturing process cost reductions and quality improvements. New and fully developed cell and bundle designs and manufacturing processes as well as some new module design features were then tested in either bundle tests (two, $3 \times 8$ bundles or 48 cells) or $5 \mathrm{kWe}$ units (four, $2 \times 11$, half length bundles or 88 half length cells) before being tested in a large field unit (1100 to 2300 cells).

\section{Cell Manufacturing Cost Reduction}

The most significant cell manufacturing cost reduction accomplishments were 1) switching from vendor supplied air electrode tubes to in-house air electrode tube making, and 2) switching from electrolyte and fuel electrode electrochemical vapor deposition (EVD) to atmospheric plasma spray (APS). From 1999 thru 2001, Siemens developed in-house air electrode tube making capability including air electrode powder synthesis, paste preparation, tube extrusion and tube sintering. This effort resulted in reducing tube cost from $\$ 1200$ per tube (NGK supplied) to $\$ 300$ per tube (in-house production). Further improvement in the air electrode powder synthesis process from 2001 to 2007 , reduced the cost to approximately $\$ 200$ per tube. The EVD process was very capital intensive, required very expensive raw materials (zirconium chloride, yttrium chloride), and required frequent maintenance due to its hostile environment. In 2003, Siemens successfully completed the development of electrolyte and fuel electrode deposition by APS. The combination of the above two developments plus smaller developments resulted in the reduction in cell manufacturing cost from about $\$ 4,000$ per cell in 1997 to about $\$ 1,000$ per cell in 2007 . This cost reduction includes the effect of an overall yield improvement from $25 \%$ to $50 \%$. 


\section{Cell Power Enhancement}

Cell power enhancement is an important way to reduce cell and module cost on $\$ / k W e$ basis. Raising cell power results in fewer cells per kWe, fewer bundles per kWe, and less module materials per kWe. The most significant cell power enhancement accomplishments were 1) composite interlayer between the air electrode and electrolyte, 2) replacing yttria stabilized zirconia (YSZ) with scandia stabilized zirconia (ScSZ) in the composite interlayer, electrolyte and fuel electrode, and 3) non-cylindrical high power density cell configurations and the Delta8 configuration in particular. (See Figure 3-1.) The Delta8 cell with a composite interlayer and ScSZ produced $600 \mathrm{~W}$ at $940^{\circ} \mathrm{C}$ and $0.65 \mathrm{~V}$ compared to the $130 \mathrm{~W}$ for the 1997 cylindrical cell. There remain operational and manufacturing issues associated with the Delta8 cell, which will be addressed in the SECA Coal-Based Hybrid program.

\section{Module Cost Reduction}

The most significant module cost reduction accomplishments were 1) switching from felt to foam top screen cell-to-cell connectors, 2) reducing the cost of high purity alumina fiber board by alternate supplier development, and 3) replacing high temperature alloy parts and fiber board parts with net shape cast ceramics. Developing the foam top screen bundle to replace the felt bundle reduced the cost of bundling from $\$ 4,000$ per kWe to $\$ 1,200$ per kWe for the $150 \mathrm{~cm}$ active length, cylindrical cell. Zircar Ceramics had a monopoly on the supply of all-alumina fiber board and their product was very expensive. In the 2001-2003 timeframe, Siemens developed Refractory Specialties, Inc. (RSI) as an alternate supplier. RSI now supplies all-alumina fiber board at a price of $\$ 66$ per board foot compared to $\$ 116$ per board foot for Zircar. There is still considerable expense, however, associated with machining fiber board ( $30 \%$ waste) to make module parts. In 1999 Siemens started working with Blasch Precision Ceramics to replace high temperature alloy parts and machined fiber board parts with net shape cast, hard ceramic parts. Whereas this development work is still ongoing under the SECA Coal-Based Hybrid program, the progress to date is very encouraging.

\section{Advanced Power Systems Development}

The most important advanced system technology achievements were the development of pressurized hybrid $(\mathrm{PH})$ technology and the conceptual design work on a "zero emissions" (ZE) SOFC power system. Pressurized hybrid power systems have the potential to achieve $60 \%$ electrical efficiency on natural gas compared to $45 \%$ for atmospheric pressure power systems. The $\mathrm{PH}$ development work consisted of module design, gas turbine modification and system integration design, pressurized cell and bundle testing, and the SCE PH-220 and RWE PH-300 field test programs.

The ZE concept consisted of producing an effluent gas stream from the SOFC power system composed of nearly pure $\mathrm{CO}_{2}$, which is amenable to $\mathrm{CO}_{2}$ sequestration. The $\mathrm{ZE}$ development work consisted of 1) developing a barrier between depleted air and depleted fuel exiting the stack, 2) developing an afterburner, which reacts the depleted fuel to at least $97 \%$ of completion, and 3) testing nickel anode cells, copper anode cells, and Praxair's oxygen transport membranes (OTMs) as the active component in the afterburner. The ZE design concept was never tested as a complete system.

\section{BOP Cost Reduction}

The most significant BOP cost reduction accomplishment consisted of moving the air/exhaust recuperator and startup heater to inside the SOFC module. This eliminated high temperature, air/exhaust piping from the BOP as well. Recuperators internal to the SOFC module (air feed tube recuperators) were tested in $5 \mathrm{kWe}$ units and the CHP-125 field unit. A cost-effective and 
reliable solution for the internal startup heating system is still under development. The highest cost BOP component is the Power Conditioning System, which has undergone very little cost reduction to date.

\section{Field Unit Test Program}

The field unit test program consisted of designing, building and site testing 5 fully integrated SOFC power systems. The CHP-100 system achieved $46 \%$ electrical efficiency, operated for 37,000 hours (33,000 hours for 528 cells), and operated at 3 sites (The Netherlands, Germany and Italy). It was the most successful of the 5 field units. The SCE PH-220 was the world's first pressurized SOFC/gas turbine combined cycle system. It achieved an electrical efficiency of $52 \%$ and operated for 3,000 hours. The OPG CHP-250 and the RWE PH-300 both produced the highest power output (193 kWe net AC) but they both had problems with their non-sealed air inlet plenum design, which impacted stack performance. Finally, the Stadtwerke Hannover CHP-125 was the first large field unit to contain all-APS cells and foam top screen bundles as well as the internal, air feed tube recuperator. Problems with the pencil type air heaters inside the air feed tubes forced the shutdown of the unit. Design modifications are being implemented and the CHP-125 unit should be ready for retest in late 2008/early 2009.

At the beginning of this Cooperative Agreement in 1997, the direct factory cost of the CHP-100 was about $\$ 65,000$ per kWe. Ten years later the direct factory cost of the CHP-125 is about $\$ 25,000$ per $\mathrm{kWe}$. The cell manufacturing cost reduction was about $\$ 25,000$ per $\mathrm{kWe}$, the SOFC module cost reduction was about $\$ 10,000$ per kWe even with the internal recuperator, and the BOP cost reduction was about $\$ 5,000$ per kWe. The above progress in reducing product cost does not consider the development work ongoing under the SECA Coal-Based Hybrid program, such as the Delta8 cell, net shape casting, and on-cell reformation. If these innovations are successfully developed, the product cost reduction will be significant and the technology should be ready for commercialization. 


\subsection{Introduction}

This report describes the technical progress made toward tubular SOFC commercialization over the time period August 1997 through September 2007 under the U. S. DOE Cooperative Agreement. The focus of the 10 year Cooperative Agreement was cell manufacturing cost reduction, cell power enhancement, module (including cell bundling) cost reduction, advanced power systems development (pressurized hybrid systems and "zero emissions" system), BOP cost reduction and demonstrating these technology advancements in customer operated field unit tests. The above topics are covered in sections 2.0 thru 8.0. Section 9.0 includes the work performed under Project Management (Task 9) of the Cooperative Agreement including the "Due Diligence" cost studies. Section 10.0 summarizes the major accomplishments and their significance, and Section 11.0 contains recommendations for future work.

At the start of the 10 year Cooperative Agreement, Westinghouse, later Siemens, was ready to start testing the first grid-connected field unit, the EDB/ELSAM (a consortium of Dutch and Danish utilities) $100 \mathrm{kWe}$ Combined Heat and Power System. This unit, in general, performed very well as described in Section 7.0 but was very expensive $(\$ 65,000$ per kWe direct factory cost). So a large effort was expended under this Cooperative Agreement to cost reduce the tubular SOFC power system by process and design changes. Even though the goal of achieving a direct factory cost of about $\$ 4,000$ per kWe for early market entry units has not yet been achieved, significant progress has been achieved in product cost reduction as described in the following sections. 


\subsection{Cell Manufacturing Development (Task 1)}

From 1997 to 2007, Siemens made very significant progress in reducing cell manufacturing cost, and improving cell yield and quality. The most significant cell manufacturing development accomplishments over this time period were 1) in-house air electrode tube making, 2) electrolyte and fuel electrode deposition by atmospheric plasma spray, and 3) interconnection high temperature stability improvement. The comparison of the 1997 cell manufacturing process with 2007 cell manufacturing process is presented in Figure 2-1. The red boxes represent materials supplied by our suppliers.

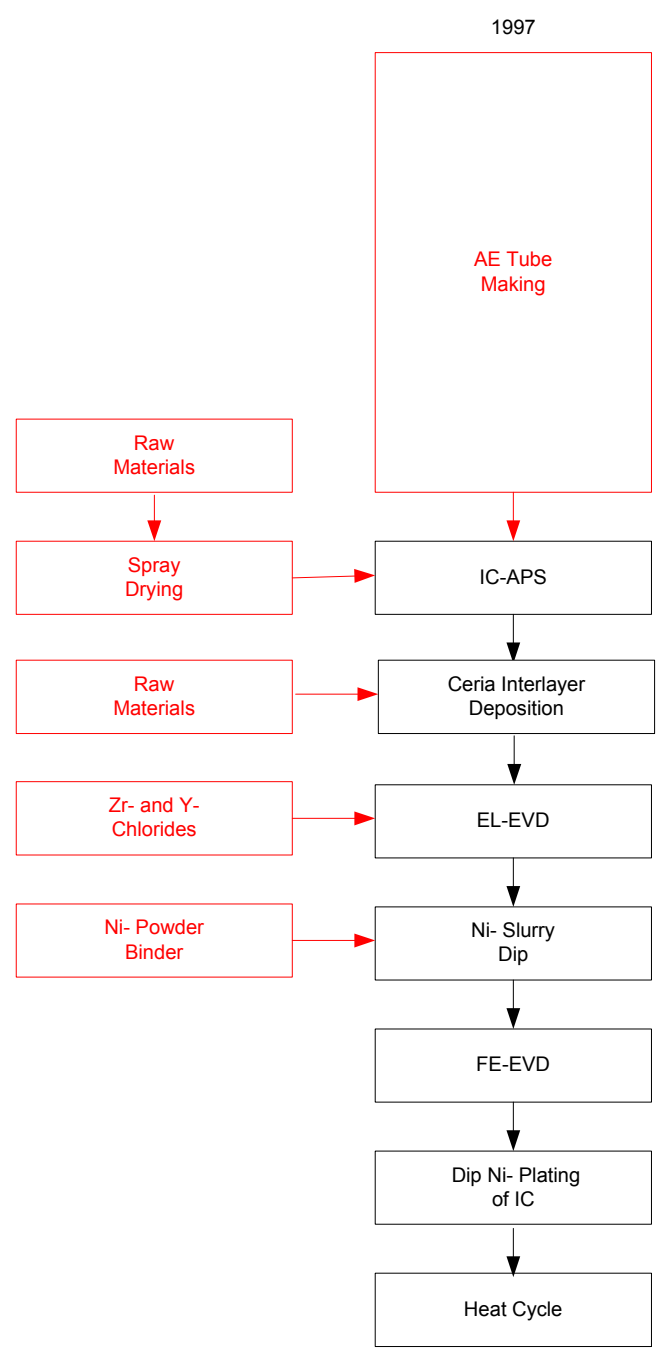

Direct Cell Cost $=\$ 4,000$

- Siemens' Scope

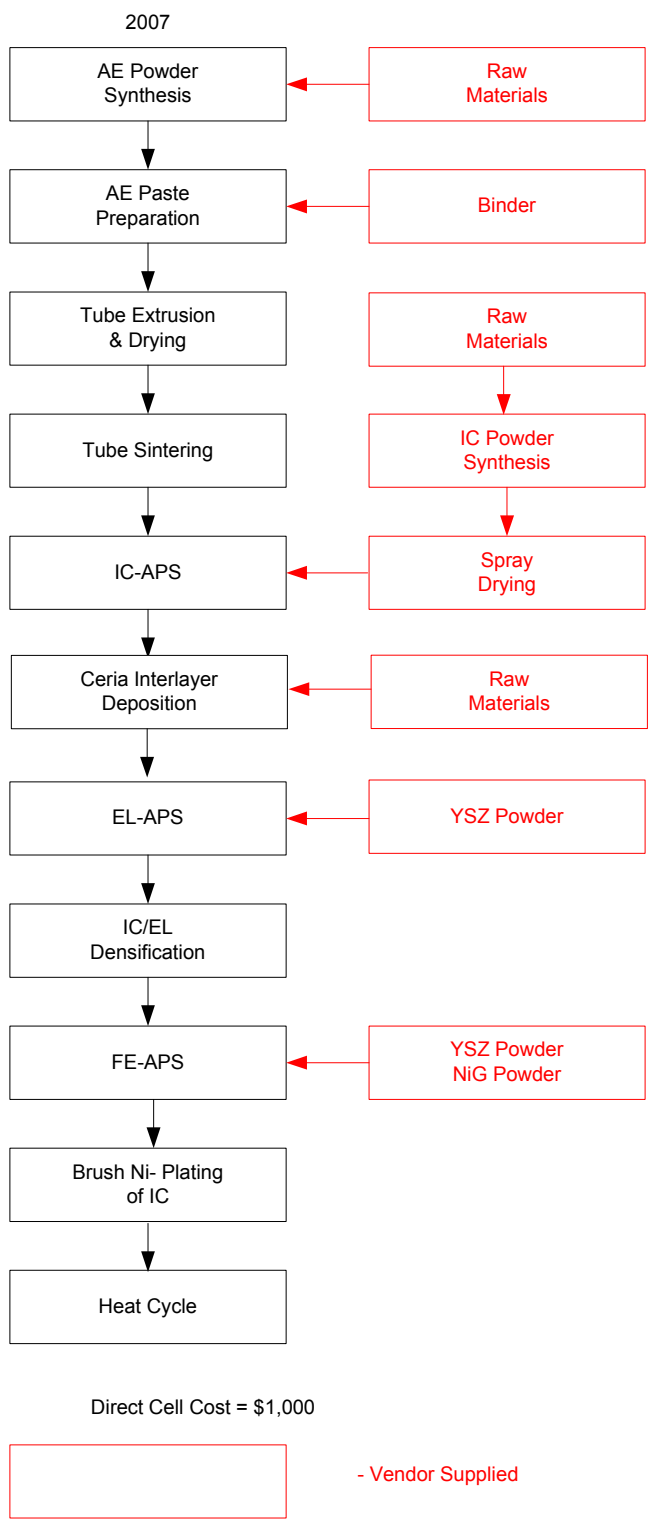

Figure 2-1 - Comparison of 1997 Tubular SOFC Manufacturing Process with 2007 Manufacturing Process 
In-House Air Electrode (AE) Tube Making)

In 1997 NGK was the AE tube supplier to Westinghouse (now Siemens). Cells made with NGK tubes found their way into the EDB/ELSAM $100 \mathrm{kWe}$ power system and the SCE $220 \mathrm{kWe}$ pressurized hybrid power system. We were not satisfied, however, with the progress NGK was making in reducing tube cost, and thus their price to us. So we attempted to find/develop an alternate supplier. In 1998 Praxair was selected as our preferred tube supplier. Unfortunately, Praxair was not successful in meeting all of our technical requirements. So in 1999, Siemens decided to develop in-house air electrode tube making capability. In 2000, the Siemens air electrode tube making process was qualified and ready for production. Siemens tubes found their way into the SCE $220 \mathrm{kWe}$ pressurized hybrid power system (stack rebuilds), the OPG 250 kWe power system, the RWE and $\mathrm{EDI}^{1} 300 \mathrm{kWe}$ pressurized hybrid power systems, and the Stadtwerke Hannover 125 kWe power system. Over 10,000 AE tubes were manufactured by Siemens for these field units.

The $A E$ tube manufacturing capability developed by Siemens included AE powder synthesis, $A E$ paste preparation, $A E$ tube extrusion and drying, and tube sintering. $A E$ powder synthesis is the process of producing $A E$ powder (doped $\left.\mathrm{LaMnO}_{3}\right)$ from precursor materials $\left(\mathrm{La}_{2} \mathrm{O}_{3}, \mathrm{MnO}_{2}\right.$, $\mathrm{CaCO}_{3}$, etc.). It involves precursor powders wet mixing and drying, calcination to produce the desired composition, and milling to produce the powder. AE paste preparation involves mixing powder, binder and water together to produce a hard "rubbery" substance called paste. This paste is then fed to an extruder where both the closed end and cylindrical section of the tube are extruded. The extruded tube is then automatically transferred to the "hot dog" roller type dryer, which maintains tube straightness during drying. The final tube processing step is tube sintering, which is a two step firing process; a horizontal, bisque firing $\left(\sim 1300^{\circ} \mathrm{C}\right)$ step to give the tube some strength followed by a vertical, hang-fire $\left(\sim 1550^{\circ} \mathrm{C}\right)$ step.

The decision to produce $A E$ tubes in-house has resulted in a tube cost reduction from $\$ 1200$ per tube in 1997 (price from NGK) to $\$ 200$ per tube in 2007 (in-house cost). The tube yield also improved from less than $50 \%$ in 1997 to about $80 \%$ in 2007 . The Siemens tube making facility has the capability to produce about 1,000 in-spec. tubes per month of the design, $2.2 \mathrm{~cm} \mathrm{O.D.}$ and $168 \mathrm{~cm}$ total length.

\section{Electrolyte and Fuel Electrode Deposition by Atmospheric Plasma Spray}

In 1997 the interconnection was deposited by atmospheric plasma spray (APS) but the electrolyte was deposited by electrochemical vapor deposition (EVD) and the fuel electrode was applied by nickel slurry dip followed by EVD. The EVD process is a high temperature $\left(1200^{\circ} \mathrm{C}\right)$, low pressure $(<1$ torr) crystal growth process whereby zirconium chloride and yttrium chloride vapors flowing on the outside of an array of porous AE tubes react with oxygen and water vapor flowing on the inside of these tubes to produce the yttria stabilized zirconia electrolyte. This process was very capital intensive (\$6 million for 108 cell EVD reactor system), required very expensive raw materials (metal chlorides), and required frequent maintenance due to its hostile environment. All the large field units with the exception of the CHP-125 utilized cells with electrolyte and fuel electrode deposited by EVD.

Even though the EVD process grew high quality, leak tight electrolyte layers, it was assessed that this deposition process was too expensive to be a large scale commercial process. So alternative electrolyte deposition processes were studied including electrolyte sintering, air electrode/electrolyte co-sintering, atmospheric plasma spray (APS), and low pressure plasma spray (LPPS). All attempts to produce leak tight electrolyte layers by sintering were

\footnotetext{
${ }^{1}$ The EDI unit was never tested.
} 
unsuccessful. The APS and LPPS processes in combination with a densification step did produce acceptable electrolyte layers. Since the APS process was considerably less expensive and further advanced in development than the LPPS process, it was decided in 1999 to proceed with the development of the APS process to replace EVD for electrolyte deposition.

The development of electrolyte APS process took about 4 years to complete but the resources assigned to this task were highly variable. The difficulty was to achieve acceptably low vacuum leak rates, cell performance equivalent to that of electrolyte EVD cells, and cell straightness within the tolerance limit all with an acceptable process step yield $(\geq 80 \%)$. The development program focused on spray parameter optimization (gun power, powder feed rate, gas flow rates, etc.) and densification conditions (temperature, time, horizontal vs. vertical). The spray parameters were optimized with the help of an in-flight particle analyzer (DPV-2000), which measures particle velocity, particle temperature and particle location within the plume. Horizontal, interconnection/electrolyte co-densification at $1345^{\circ} \mathrm{C}$ for 17 hours was selected in order to achieve acceptable cell straightness, acceptable cell performance, and acceptable vacuum leak rate. A 24 station, 3-gun APS booth (booth 4) dedicated for electrolyte deposition was installed in 2002 and the electrolyte APS process was qualified for production in early 2004.

Concerning fuel electrode deposition, two competing processes were evaluated: fuel electrode sintering and fuel electrode APS. The fuel electrode sintering process consists of masking the cell interconnection, dipping an electrolyte assembly (cell processed thru interconnection/electrolyte densification) into a $77 \mathrm{wt} \%$ nickel / $23 \mathrm{wt} \%$ YSZ slurry, and attaching the fuel electrode to the electrolyte by sintering @ $1300^{\circ} \mathrm{C}$ in a dual atmosphere sintering furnace (air flowing on the cell inner surface and a reducing gas flowing on the cell outer surface). This dual atmosphere furnace is necessary to avoid nickel oxidation and delamination of the fuel electrode. The fuel electrode APS process consists of masking the cell interconnection and plasma spraying a powder consisting of nickel coated graphite (NiG) particles and YSZ particles. The graphite is required to prevent over-densification of the fuel electrode during plasma spray and is removed during the subsequent heat cycle and bundle sintering steps by reacting it with $\mathrm{H}_{2} \mathrm{O}$.

The FE sintering process was dropped in 2000 in favor of the FE APS process for two reasons: 1) the FE sintering process was more expensive due to the need for a dual atmosphere sintering step, and 2) performance testing of cells with APS-electrolyte and APS-fuel electrode showed encouraging test results. The fuel electrode APS development program focused on spray parameter optimization, and spray powder (NiG/YSZ) blend ratio optimization. A 24 station, 3-gun APS booth (booth 3) dedicated for fuel electrode deposition was installed in 2002 and the fuel electrode APS process was qualified for production in early 2004.

Over 300 cell tests of all-APS (IC, EL, FE) cells have been performed. One cell test of an early prototype all-APS cell (test 675), in particular, exhibited cell performance equivalent to that of an EVD cell and operated for 17,000 hours with no observable voltage degradation. In addition, a total of 264, $70 \mathrm{~cm}$ active length, all-APS cells were tested in three $5 \mathrm{kWe}$ units and 1140, $150 \mathrm{~cm}$, active length, all-APS cells were tested in the CHP-125 unit.

\section{Interconnection High Temperature Stability}

In 1997, the interconnection was deposited by atmospheric plasma spray. The plasma spray powder designated LCCA (lanthanum chromite/çalcium aluminate) was made by first mixing together lanthanum chromite, calcium aluminate and chromium oxide powders, and then spray drying the mixture to form agglomerates for flowability. Calcium aluminate was the sintering aid and chromium oxide was added to compensate for preferential chromium oxide volatilization 
during plasma spray deposition. This resulted in non-uniform as-deposited interconnection chemistry (microscopic areas of excess La, microscopic areas of excess $\mathrm{Cr}$ ). After operation over time at temperatures $\geq 1000^{\circ} \mathrm{C}$, interconnection porosity formed due to migration of excess chromium oxide into the air electrode. This porosity formation led to premature cell failure due to hydrogen attack of the air electrode material under the interconnection.

In 2002, an improved plasma spray powder making process was developed called "sintered and crushed" (SC). This powder making process consists of 1) mixing precursor materials $\left(\mathrm{La}_{2} \mathrm{O}_{3}\right.$. $\mathrm{CaCO}_{3}, \mathrm{Cr}_{2} \mathrm{O}_{3}, \mathrm{Al}_{2} \mathrm{O}_{3}$ ) together, 2) chemically reacting these materials via sintering at elevated temperature, 3 ) crushing the reacted material down to fine powder, and 4) spray-drying the fine powder to form agglomerates. Interconnections (ICs) plasma sprayed with SC powder showed much improved high temperature stability compared to ICs sprayed with LCCA powder due to a more homogeneous IC chemistry and the need for less excess chromium oxide. The SC process was incorporated into production in 2003.

\section{Conclusion}

Significant progress has been made over the last 10 years on reducing cell manufacturing cost ( $\$ 4000$ per cell in 1997 to about $\$ 1000$ per cell in 2007). The major contributors to this cost reduction were 1) in-house air electrode tube making and 2) replacement of EVD with APS for electrolyte and fuel electrode deposition. Another very noteworthy development was the significant improvement in high temperature interconnection stability and thus cell life by switching from LCCA plasma spray powder to SC plasma spray powder.

For early market commercialization, cell manufacturing cost must be below $\$ 100$ per cell for the standard $150 \mathrm{~cm}$ active length, cylindrical cell. It has been evaluated many times that this can be achieved by 1) increasing production volume (lower raw materials cost and lower overhead), 2) automating cell handling and inspection (lower labor content), and 3) raising yield above the current value of $50 \%$ by continuing to investigate the root causes of rejection. 


\subsection{Cell Technology Development (Task 2)}

This section discusses the accomplishments in cell power enhancement and atmospheric pressure cell testing.

\section{Cell Power Enhancement}

Increasing cell power output (W per cell), cell specific power (W per kg of cell material) and cell power density (W per $\mathrm{cm}^{3}$ of cell volume ${ }^{2}$ ) are very important, if not essential, to reducing cell and module cost on a $\$ / \mathrm{kWe}$ basis. At the beginning of this Cooperative Agreement in 1997, the standard cell was a $2.2 \mathrm{~cm}$ O.D., $150 \mathrm{~cm}$ active length, air electrode supported cell with a discontinuous ceria interlayer between the air electrode and electrolyte. At $940^{\circ} \mathrm{C}$ (typical cell average temperature in a generator), this cell design produces $130 \mathrm{~W}$ per cell, $118 \mathrm{~W}$ per $\mathrm{kg}$ and $0.113 \mathrm{~W}$ per $\mathrm{cm}^{3}$ at $0.65 \mathrm{~V}$, which roughly corresponds to a power system electrical efficiency of $45 \%$ (net AC/LHV) on natural gas.

\section{Composite Interlayer}

The first cell power enhancement innovation under development was the composite interlayer, a $5 \mu \mathrm{m}$ layer located between the air electrode and electrolyte intended to reduce charge transfer polarization. The composite interlayer consists of a mixture of fine air electrode powder and fine YSZ powder sintered together. An ink of the 2 phase mixture is applied to the air electrode surface by roller coating followed by a $1200^{\circ} \mathrm{C}$ calcination step. The electrolyte is then deposited over the composite interlayer by atmospheric plasma spray. Cell testing of this innovation repeatedly demonstrated a $15 \%$ increase in cell power at $0.65 \mathrm{~V}$ and $940^{\circ} \mathrm{C}$ (generator operating conditions) relative to the standard cell at $0.65 \mathrm{~V}$ and $940^{\circ} \mathrm{C}$. A $30 \%$ increase in cell power was realized at $0.65 \mathrm{~V}$ and $900^{\circ} \mathrm{C}$.

\section{Scandia Stabilized Zirconia (ScSZ)}

ScSZ has a higher ionic conductivity than YSZ at temperatures below $1000^{\circ} \mathrm{C}$. Cell testing of a composite interlayer cell (Test 1106) has shown that replacing YSZ with ScSZ in the electrolyte and in the composite interlayer increases cell power by $21 \%$ (15\% composite $\mathrm{I} / \mathrm{L}, 5 \% \mathrm{ScSZ})$ at $0.65 \mathrm{~V}$ and $940^{\circ} \mathrm{C}$ and by $43 \%(30 \%$ composite $\mathrm{I} / \mathrm{L}, 10 \% \mathrm{ScSZ})$ at $0.65 \mathrm{~V}$ and $900^{\circ} \mathrm{C}$ relative to the standard cell. The longest running composite interlayer cell with scandia substituted for yttria in the electrolyte and composite interlayer is Test 1106 . This cell operated at $1000^{\circ} \mathrm{C}$ for 2000 hours and $900^{\circ} \mathrm{C}$ for 3300 hours and showed stable performance. In addition, a $5 \mathrm{kWe}$ generator (Alpha 7) with $88,70 \mathrm{~cm}$ active length, composite interlayer/ScSZ cells was built and tested in 2005. It operated for over 1200 hours and confirmed the cell power increases stated above. The problem with scandia is that its price is considerably higher than that of yttria and is very sensitive to demand since the world production volume of scandia is relatively small.

\section{High Power Density Cell Configurations}

High power density cell configurations are non-cylindrical geometries aimed at increasing active surface area and reducing the average current path length within the air electrode, thereby reducing the cell resistance index $\left(\Omega \mathrm{cm}^{2}\right)$ and flattening the cell voltage - current density curve. In addition, increased power per cell is desirable, enabling fewer cells per kW. Two such configurations, HPD5-R1 and Delta8 are shown in Figure 3-1 and their performance is discussed below.

\footnotetext{
${ }^{2}$ Cell volume $=(\text { pitch })^{2} \times \mathrm{L}$
} 


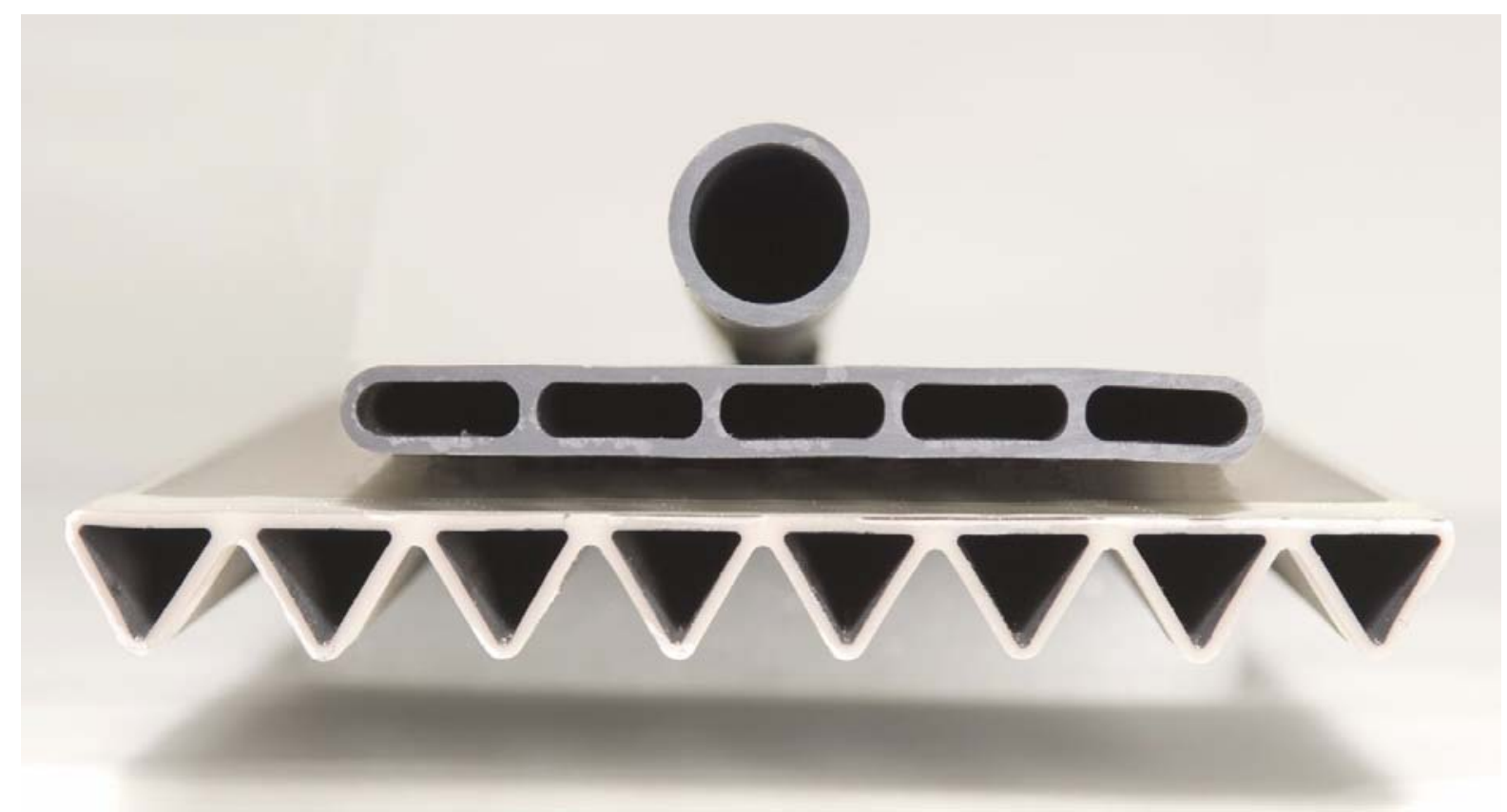

Figure 3-1 - Cross Sections of Cylindrical, HPD5-R1 and Delta8 Cells

As shown in Figure 3-1, HPD5-R1 has 5 air channels. R1 stands for revision 1, which incorporated larger radii of curvature and a slightly thicker air electrode. The current flow path is from the fuel electrode thru the electrolyte to the air electrode and then thru the air electrode ribs (4) and ends (2) to the interconnection. The dimensions of HPD5-R1 are $10 \mathrm{~cm}$ wide, $1.0 \mathrm{~cm}$ deep and $100 \mathrm{~cm}$ long. The length is limited to $100 \mathrm{~cm}$ due to issues with straightness. Testing of HPD5-R1 cells with an YSZ composite interlayer and electrolyte have demonstrated a cell power output of $180 \mathrm{~W}$ at $0.65 \mathrm{~V}$ and $940^{\circ} \mathrm{C}$. This compares to $150 \mathrm{~W}(=130 \times 1.15)$ for the 150 $\mathrm{cm}$ active length, cylindrical cell with an YSZ composite interlayer and electrolyte, a 20\% power increase. Relative to the standard cell, the cell power enhancement is $38 \%$. When scandia was substituted for yttria in the composite interlayer, electrolyte and fuel electrode, the HPD5-R1 cell power increased to $190 \mathrm{~W}$ at $0.65 \mathrm{~V}$ and $940^{\circ} \mathrm{C}$.

Under the SECA program, a proof-of-concept (POC) unit was built and tested in 2006 with the latest technology (composite I/L, scandia) HPD5-R1 cells. Using the $5 \mathrm{kWe}$ generator design as a starting point, the $88,70 \mathrm{~cm}$ active length, cylindrical cells were replaced with $36,76 \mathrm{~cm}$ active length HPD5-R1 cells. The POC unit operated for 7,000 hours and produced $5.9 \mathrm{kWe}$ DC (max.) compared to $5.4 \mathrm{kWe}$ DC (max.) for the $5 \mathrm{kWe}$ generator incorporating scandia tubular cells.

The Delta8 cell is being developed under the SECA hybrid program. It is a much larger cell (2000 $\mathrm{cm}^{2}$ active area) compared to HPD5-R1 $\left(900 \mathrm{~cm}^{2}\right)$, and the standard cylindrical cell (810 $\mathrm{cm}^{2}$ ). Its dimensions are $15 \mathrm{~cm}$ wide, $1.5 \mathrm{~cm}$ deep and $83 \mathrm{~cm}$ long. A cell test of a Delta8 cell with a composite interlayer and ScSZ resulted in a cell power output of $530 \mathrm{~W}$ per cell at $0.7 \mathrm{~V}$ and $940^{\circ} \mathrm{C}$. Extrapolating to $0.65 \mathrm{~V}$, the cell power output would have been $600 \mathrm{~W}$ per cell.

Table 3-1 summarizes the performance comparison of the various cell designs. 
Table 3-1 - Performance Comparison of Various Cell Designs

\begin{tabular}{|l|c|c|c|}
\hline \multicolumn{1}{|c|}{ Cell Design } & $\begin{array}{c}\text { Cell Power } \\
(\mathrm{W})\end{array}$ & $\begin{array}{c}\text { Cell Specific }_{\text {Power }^{(1)}} \\
(\mathrm{W} / \mathrm{kg})\end{array}$ & $\begin{array}{c}\text { Cell Power }^{(1)} \\
\text { Density }^{(1)} \\
\left(\mathrm{W} / \mathrm{cm}^{3}\right)\end{array}$ \\
\hline Std. Cell & 130 & 118 & 0.113 \\
\hline Std. Cell + Composite I/L & 150 & 136 & 0.130 \\
\hline Std. Cell + Composite I/L + ScSZ & 157 & 143 & 0.136 \\
\hline HPD5-R1 + Composite I/L & 180 & 90 & 0.138 \\
\hline HPD5-R1 + Composite I/L + ScSZ & 190 & 95 & 0.146 \\
\hline Delta8 + Composite I/L + ScSZ & 600 & 240 & 0.300 \\
\hline
\end{tabular}

${ }^{(1)}$ All performance values at $940^{\circ} \mathrm{C}$ and $0.65 \mathrm{~V}$.

\section{Atmospheric Pressure Cell Testing}

During the 10 year Cooperative Agreement, over 600 cell tests were performed in 13 test stands (11 for up to $70 \mathrm{~cm}$ active length cells and 3 for up to $200 \mathrm{~cm}$ active length cells). Cell testing has provided the necessary performance feedback for all of our cell development initiatives and some of our SOFC generator development initiatives. The list below itemized the types of cell tests performed over the 10 year period.

- Performance feedback on cell design innovations: $150 \mathrm{~cm}$ active length cylindrical cell, composite interlayer, scandia, HPD5-R0 and -R1, Delta type cells, etc.

- Performance feedback on manufacturing process development activities: APS of interconnection, electrolyte, and fuel electrode, in-house manufacture of air electrode powder and tubes, LPPS of electrolyte, etc.

- Performance qualification of cell manufacturing batches for use in field units.

- Performance qualification of fully developed manufacturing processes.

- Performance feedback of certain SOFC bundle and generator design initiatives: foam top screens, mullite air feed tubes, silica containing insulation, high temperature seals, etc.

- Experimental determination of cell limits of operation: lifetime vs. operating temperature, low voltage limits, thermal cycles.

- Experimental determination of cell performance characteristics: V-J curves at various operating temperatures over the range $600-1000^{\circ} \mathrm{C}$, high temperature leak vs. temperature, ohmic resistance, cathode and anode polarizations.

\section{Conclusion}

Cell power enhancement is probably the most effective way of reducing cell and module cost on a $\$ / \mathrm{kWe}$ basis. It has been shown that the Delta8 cell power is 4 times greater than that of the state-of-the-art cylindrical cell (600 W vs. $157 \mathrm{~W})$. The concern with these non-cylindrical cell configurations, however, is thermal stress induced cell cracking in a generator environment. Delta8 development and cell, bundle, and generator testing will go forward under the DOE SECA Coal-Based Hybrid program. 


\subsection{Module Cost Reduction and Technology Development (Tasks 3 and 4)}

At the start of the Cooperative Agreement in 1997, the state-of-the-art in SOFC generator (or module) design was the EDB/ELSAM $100 \mathrm{kWe}$ generator. The technology consisted of 1) 150 $\mathrm{cm}$ active length, $3 \times 8$ cell bundles with felt strips as the cell-to-cell connectors, 2) machined, high purity alumina, fiber board components such as stack reformer boards, fuel distribution boards, upper positioning boards, etc., 3) high purity insulation surrounding the cell stack, 4) high temperature (up to $900^{\circ} \mathrm{C}$ ), Inconel air inlet boxes, 5) Inconel fuel recirculation loop components, 6) high purity alumina air feed tubes and 7) a stainless steel, $750^{\circ} \mathrm{C}$ stack container, which forms the pressure boundary for fuel and exhaust. The design functioned very well, as described in Section 7.0, but was too expensive due to the labor intensive bundling process, extensive machining of high purity alumina, fiber board ( $30 \%$ waste), the extensive use of expensive alloys and the use of expensive, high purity insulation bricks between the stack and container. In addition, conceptual design work had just begun on the pressurized SOFC module for the world's first pressurized hybrid (PH) SOFC power system, the PH-220.

This section describes the major technology development and cost reduction initiatives for the SOFC module during the 10 year Cooperative Agreement. These initiatives are categorized as follows: pressurized hybrid technology, bundling, ceramic components, metallic components, and zero emissions (ZE) technology.

\section{Pressurized Hybrid Technology}

Pressurizing the SOFC module improves power system performance 1) by raising the fuel cell thermodynamic potential (higher oxygen partial pressure on cathode side) and 2) by providing high temperature/high pressure exhaust to drive a gas turbine generator. Both the EDB/ELSAM 100 kWe Power System and the SCE PH-220 Power System utilized the same cell stack design (1152 cells). The PH-220 cell stack operated at 3 atmospheres (abs.) and produced $170 \mathrm{kWe}$ DC compared to $125 \mathrm{kWe}$ DC for the $100 \mathrm{kWe}$ cell stack.

In a collaborative program with Ontario Hydro Technologies (later renamed Kinectrics), two pressurized cell test stands and a pressurized bundle test facility were built at their site in Toronto, Canada. Pressurized cell testing took place intermittently from 1997 to 2001 . Testing included V-J curves at $1000^{\circ} \mathrm{C}$ and at various pressures up to $15 \mathrm{~atm}$. absolute, endurance testing at 3 to 5 atm. absolute for $>5000$ hours, and thermal cycle testing from elevated pressure. Figure 4-1 presents measured V-J curves at various pressures and shows the performance benefit of pressurization. For example, at $0.65 \mathrm{~V}$ the current density at $3 \mathrm{~atm}$. is $26 \%$ higher than that at $1 \mathrm{~atm}$. Testing of the first pressurized bundle test article (two $3 \times 8$ cell bundles plus stack reformers and recirculation loop) took place in 1998. There were two lessons learned from this test: 1) a stack liner is needed to reduce fuel bypass and 2) cell open end (OE) sleeves are needed to help prevent OE chipping and cracking especially during rapid depressurization. The second pressurized bundle test article operated very well for over 6000 hours and confirmed the effectiveness of the natural gas stack reformers at $3 \mathrm{~atm}$. up to a cell average current density of $330 \mathrm{~mA} / \mathrm{cm}^{2}$. Pressurized bundle testing was completed in 2001 . 


\section{AES - SOFC Pressurized Endurance Test Results}

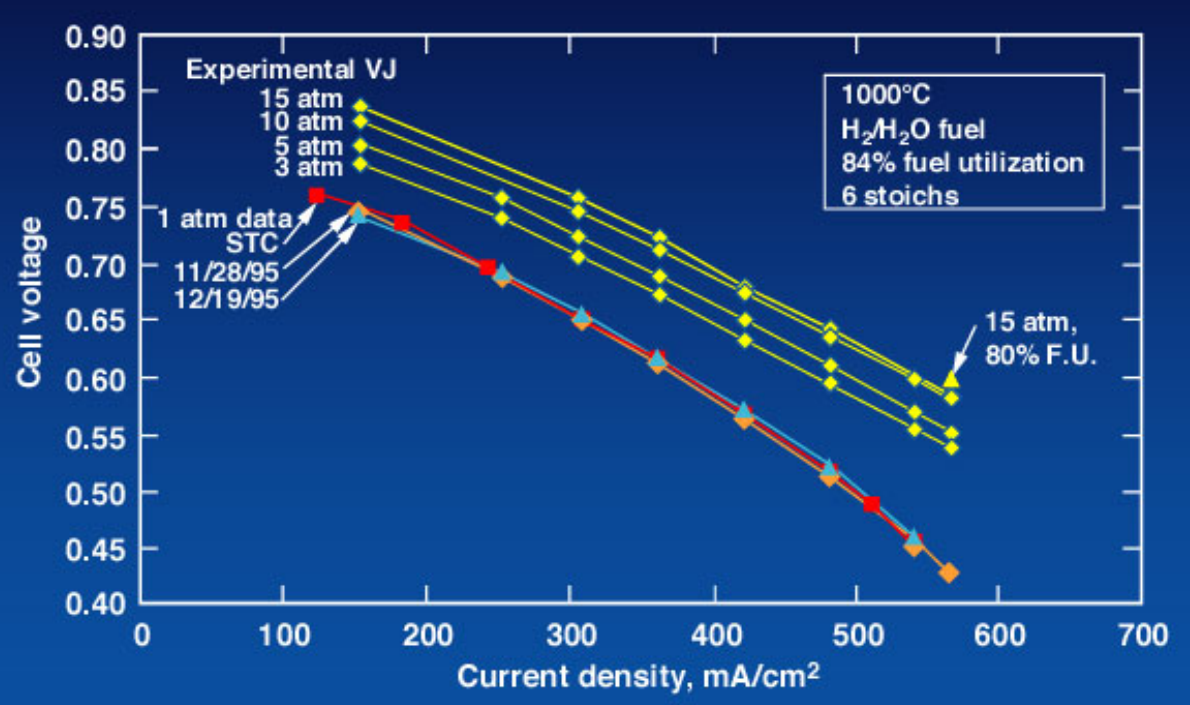

Figure 4-1 - Measured Cell Voltage vs. Current Density at Various Pressures

The PH-220 SOFC module design was based, to a large degree, on the $100 \mathrm{kWe}$ module design. The high temperature, stainless steel stack container of "square" cross section was replaced with a low temperature, carbon steel, vertical pressure vessel of cylindrical cross section. The space between the cell stack and pressure vessel was filled with low cost (silica containing) insulation. A thin $(0.3 \mathrm{~mm})$, Haynes liner was placed around the cell stack to prevent fuel from bypassing the stack and to prevent silicon vapor species from entering the stack. In addition, air and exhaust piping plus inlet/outlet isolation valves, which prevent rapid pressure vessel depressurization, were located within the pressure vessel.

Based on lessons learned from the $\mathrm{PH}-220$ operation and cost reduction initiatives, a number of significant design improvements were incorporated into the SOFC module for the $\mathrm{PH}-300$ (world's second pressurized hybrid power system). The cell stack was placed in a inner container of "square" cross section and open at the top. The inner container was placed inside a horizontal pressure vessel insulated on its inner surface. Pressurized, inlet air filled the large volume between the inner container and pressure vessel insulation. This space, called the Integrated Air Accumulator, provided the air flow to the cell stack during depressurization when gas turbine air flow was lost. This design feature eliminated the need for a high pressure auxiliary air flow system in the BOP. In addition, the expensive, high temperature air inlet boxes were replaced with ceramic plates, which supported the air feed tubes and sealed against the walls of the inner container. These plates were intended to prevent the higher pressure inlet air from leaking into the exhaust and fuel space. Unfortunately, this "open plenum" design concept did not seal adequately and had a negative effect on cell stack performance as discussed in Section 8.0. 


\section{Bundling}

In 1997 , the bundling process was very expensive $(\$ 10,000$ per $3 \times 8$ bundle or $\$ 4,000 / \mathrm{kWe})$. It consisted of making nickel fiber pads and laser cutting these pads into strips, $7 \mathrm{~mm} \times 7 \mathrm{~mm} \times$ $370 \mathrm{~mm}$ long. Then 172 (43 44 axial sections) such nickel felt strips were manually "glued" to a $3 \times 8$ array of cells using a nickel/PVA slurry as the wetting agent, as shown in Figure 4-2. The "glued" bundle was then sintered at $1025^{\circ} \mathrm{C}$ in a dual atmosphere furnace to form nickel sinter bonds between the felts and cells.

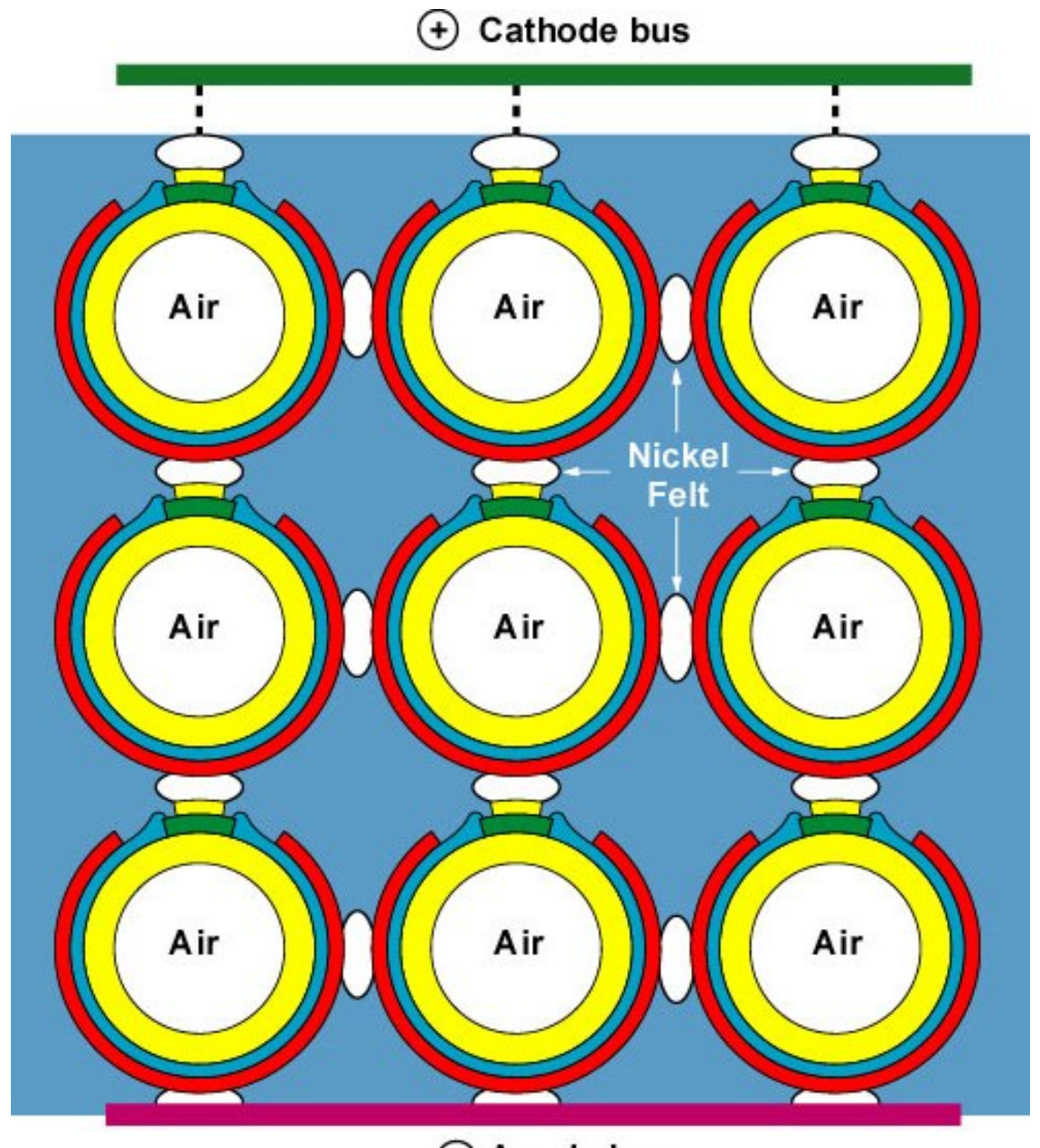

$\odot$ Anode bus

Figure 4-2 - Cross Section of Nickel Felt Bundle

In 2003, a cell-to-cell connector, called the foam top screen connector, was developed. This connector consists of a shaped nickel screen with a nickel foam strip sintered to each of 3 crowns as shown in Figure 4-3. The foam top screen connectors were glued to the cells using a nickel epoxy instead of the nickel/PVA slurry and then the glued bundle was sintered as before. This connector was proven in five, $5 \mathrm{kWe}$ generators (each generator contained four, $2 \times 11$ bundles of $70 \mathrm{~cm}$ active length) before it was incorporated into the full length $3 \times 8$ bundling process. The CHP-125 was the first large field unit to test the foam top screen connectors. (See Section 8.0.) The bundling cost for this unit was $\$ 3,000$ per $3 \times 8$ bundle or $\$ 1,200 / \mathrm{kWe}$, a $70 \%$ reduction compared to previous units. 


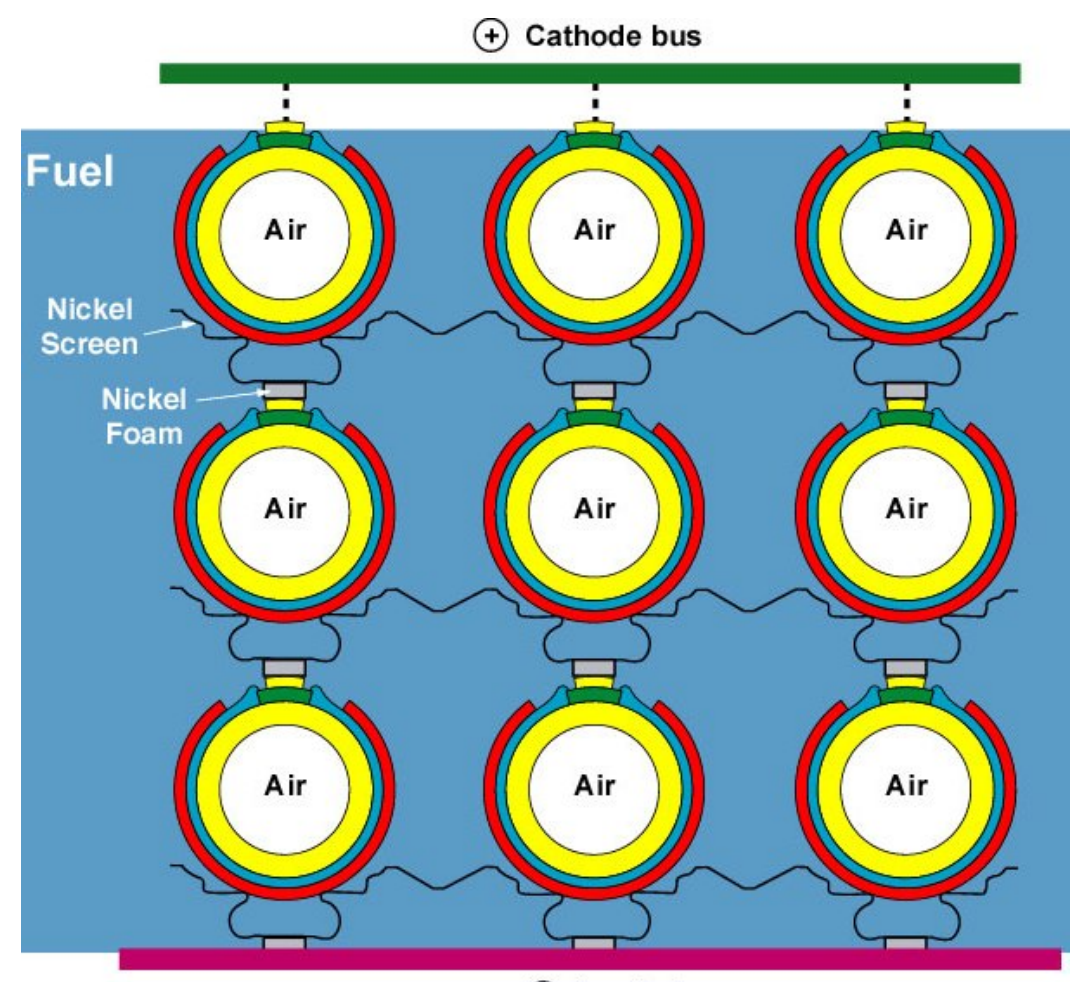

$\bigodot$ Anode bus

Figure 4-3 - Cross Section of Foam Top Screen Bundle

Even though a substantial cost reduction has been achieved, the bundling cost is still too high due to high labor content. In the 2001-2003 timeframe, an automated bundling machine was designed, built and tested. The trial runs gave us confidence that such a machine is viable but this particular machine was never put in production because it required further development work and modification before it could achieve quality and reliability requirements. In addition, this bundling machine was not applicable to HPD or Delta cells. On the other hand, manual bundling of Delta8 cells will probably cost around $\$ 200 / \mathrm{kWe}$ due to the higher cell power (Delta8: 600W vs. cylindrical: $150 \mathrm{~W}$ ) and simplification in bundling.

\section{Ceramic Components}

High purity alumina ( $3 \%$ silica), fiber board is used extensively in the cell stack because of its compliance under load, resistance to cracking, and light weight (88\% porous). Cell stack components, such as fuel distribution boards, stack reformer boards (SRB) and upper positioning boards, are machined from these fiber boards. These components function very well but are very expensive due to the high purity fiber manufacturing process and the extensive waste $(30 \%)$ produced during fiber board machining. So three different approaches were taken in an attempt to reduce the cost of these components: 1) low purity fiber board, 2) net shape casting, and 3) alternate supplier development.

Low purity ( $40 \%$ silica) fiber board samples were included in cell tests to evaluate the effect of this material on cell voltage stability. It was concluded that this material had a measurable negative effect on voltage stability for fiber board sample temperatures in the $950-1000^{\circ} \mathrm{C}$ range. Cell testing with low purity fiber board samples at lower temperatures (e.g., cell at 
$950^{\circ} \mathrm{C}$, sample at $800^{\circ} \mathrm{C}$ ) was not performed. As a result, only high purity alumina, fiber board was used inside the cell stack liner in all the field units described in Sections 7.0 and 8.0. Low purity insulation, however, was used outside the cell stack liner in all the field units after the CHP-100.

Another way to reduce the cost of the high purity alumina, fiber board-based module components is to replace board machining with net shape casting. In-house net shape casting was under development as a low priority over the time period 1999-2001. Siemens was successful in making fiber board samples with the desired properties, on an experimental basis. In 2001, however, it was decided to abandon development of in-house fiber board manufacture in favor of development of an alternate supplier to Zircar Ceramics, our only high purity alumina, fiber board supplier at the time. In 2001, Refractory Specialties, Inc. (RSI) was selected as the alternate supplier and Siemens supported their development work for 2 years. In 2003, RSI was supplying all-alumina fiber board at a price of $\$ 66$ per board foot compared to $\$ 116$ per board foot of Zircar. While this was a significant cost reduction, the goal of achieving net shape casting of module components was not yet achieved.

Siemens started working with Blasch Precision Ceramics in 1999 as part of a SBIR program, and in 2002 Siemens selected Blasch as a development partner under the SECA program. Blasch specializes in producing net shape cast ceramic parts where the raw material is ceramic particles not fiber. These parts are generally high density $(72 \%$ of theoretical density) and hard compared to low density (12\% of theoretical density) and compliant for fiber board. Due to their hardness, Blasch net shape components cannot be in direct contact with the SOFC. A compliant layer, such as an alumina felt, must be inserted between the cell and component. In addition, due to their low porosity, Blasch components are not suitable as inner stack reformer boards (SRBs). Nevertheless, the SRB end caps were net shape cast by Blasch for the Stadtwerke Hannover CHP-125 unit. In addition, the internal recuperators for the second CHP125 unit were also net shape cast by Blasch but they may never be tested. As part of the SECA Coal-Based Hybrid program, Blasch is working with Siemens to develop net shape cast ceramic components for the advanced SOFC module.

The air feed tube material for all units prior to the CHP-125 unit was high purity alumina costing $\$ 30$ per tube or $\$ 300$ per kWe in production quantities. Mullite $(60$ mole $\%$ alumina, 40 mole $\%$ silica) was selected as the air feed tube material for the CHP-125 unit costing $\$ 11$ per tube or $\$ 110$ per $\mathrm{kWe}$. The concern with mullite is the long term loss of strength in the presence of high temperature exhaust gas $\left(5 \% \mathrm{H}_{2} \mathrm{O}\right)$. Post-test inspection of the CHP-125 unit revealed that some air feed tubes cracked due to over-temperature swelling of the pencil air heaters located inside the tubes. (See Section 8.0 for a better understanding). The rebuild of the CHP-125 module will return to alumina air feed tubes. More testing is required on mullite.

\section{Metallic Components}

In 1997, the state-of-the-art in SOFC module design was the EDB/ELSAM 100 kWe generator. Many of the module components were made from expensive, high temperature alloys. The ejector/prereformer assemblies, fuel distribution pipes, SRB riser tubes, and air inlet boxes were all made from Inconel 600. The stack liner was made from Haynes 214, the SRB liners from nickel and the generator container from stainless steel 316L. The following paragraph highlights the progress made in replacing these expensive, high temperature alloys with less expensive materials.

The $5 \mathrm{kWe}$ generators were the first SOFC generators to utilize and successfully demonstrate an internal, air feed tube, ceramic recuperator and a low temperature, air inlet manifold. Based 
on the success of the $5 \mathrm{kWe}$ units, the CHP-125 module was also designed with internal, air feed tube, ceramic recuperators and low temperature, low cost air inlet boxes. In addition, the CHP-125 module replaced the fuel distribution pipes and SRB riser tubes with ceramic fuel channels and alumina riser tubes. Whereas these are important cost reduction design features, as of this writing, insufficient operating hours ( 1100 hours) were accumulated on the CHP-125 to have proven the long term stability of these design features. Long term, high temperature creep of recuperators and progressive joint leakage in the fuel distribution system are two areas of concern. Finally, the CHP-125 module container was a lower temperature design and made of carbon steel vs. stainless steel for the EDB/ELSAM $100 \mathrm{kWe}$ generator.

\section{Zero Emissions (ZE) Technology}

In the 2001 to 2003 timeframe, under a development program with Shell Oil and with the support of DOE, Siemens attempted the development of an SOFC module that segregates the depleted fuel $\left(52 \% \mathrm{H}_{2} \mathrm{O}, 28 \% \mathrm{CO}_{2}, 15 \% \mathrm{H}_{2}\right.$ and $\left.5 \% \mathrm{CO}\right)$ from the depleted air and delivers the depleted fuel to an afterburner section. The afterburner reacts the residual $\mathrm{H}_{2}$ and $\mathrm{CO}$ with oxygen using oxygen transport membranes (OTMs) or fuel cells. In the case of OTMs, $100 \%$ of the residual $\mathrm{H}_{2}$ and $\mathrm{CO}$ would be reacted. In the case of fuel cells in the afterburner, about $3 \%$ $\mathrm{H}_{2}$ plus $\mathrm{CO}$ remains (down from 20\%) due to nickel oxidation issues.

In the case of an OTM afterburner, the $\mathrm{H}_{2} \mathrm{O}$ in the fuel side exhaust is then condensed leaving a nearly pure $\mathrm{CO}_{2}$ stream for sequestration. In the case of an SOFC afterburner, the residual $3 \%$ fuel in the fuel side exhaust is first combusted with air before the $\mathrm{H}_{2} \mathrm{O}$ is condensed leaving a gas stream consisting of $86 \% \mathrm{CO}_{2}$ and $14 \% \mathrm{~N}_{2}$.

In all previous SOFC generator designs, the depleted fuel and depleted air enter the combustion zone and react. So the technology challenge for a ZE generator design is the separation of depleted fuel from depleted air by some sort of barrier or seal. A viscous seal (e.g., glass seal) was judged not viable due to the high operating temperature and the need for extremely tight tolerances. So a steam barrier was selected as the preferred solution. A steam plenum was placed between the depleted air zone and the depleted fuel zone. Steam at a slightly higher pressure than the depleted air and depleted fuel enters the steam plenum and leaks into both zones, thereby separating depleted air and fuel. This steam barrier is required in both the SOFC generator and afterburner.

The purpose of the afterburner is to react the residual $\mathrm{H}_{2}$ and $\mathrm{CO}$ in the depleted fuel exiting the SOFC generator with pure oxygen. Siemens tested various OTMs made by Praxair and successfully demonstrated complete reaction of the residual $\mathrm{H}_{2}$ and $\mathrm{CO}$. The performance of the OTMs, however, degraded over time. Concerning the SOFC afterburner, cell testing was performed up to $97 \%$ fuel consumption for both nickel anode SOFCs and copper anode SOFCs. Stable performance was demonstrated but the cell performance degraded when the fuel consumption was raised to about $99 \%$ due to nickel and copper oxidation.

In 2003 it was decided to stop work on the ZE concept due to 1) operating problems with the CHP-250 and $\mathrm{PH}-300,2)$ insufficient engineering resources, and 3) the perceived complexities of the ZE concept. Siemens is currently developing an advanced module design with Delta8 cells under the SECA Coal-Based Hybrid program. It contains some unique design features, which more readily lends itself to a ZE concept. Following successful testing of the advanced module, the ZE concept should be re-visited. 


\section{Conclusion}

Over the last 10 years significant progress was made in cost reducing the SOFC generator but a cost competitive SOFC generator design has still not been achieved. The technical approach consisted of 1) reducing bundling labor, 2) replacing high temperature alloy components with ceramic components, and 3) cost reducing ceramic components by supplier development, material composition changes and net shape casting. Siemens was successful in developing a pressurized SOFC generator and the benefits of the pressurized hybrid concept have been clearly demonstrated. An attempt was made to develop a ZE SOFC generator/afterburner but the program was stopped. This concept should be re-visited once a cost-competitive SOFC generator design is achieved and validated by test. Finally a very important way to reduce the cost of the SOFC generator is to raise cell power. Fewer cells per kWe means less generator materials and fewer labor hours per kWe. The advanced module design under the SECA CoalBased Hybrid program, reflects the lessons learned over the last 10 years and appears to be on track to achieving the commercial cost reduction targets. 


\subsection{System Cost Reduction and Technology Development (Task 5)}

The balance-of-plant (BOP) accounts for about 30 to $40 \%$ of the direct factory cost for a market entry CHP system. The BOP consists of the air supply system, fuel supply system, purge gas system, power conditioning system (PCS), electrical distribution system, heat recovery system, instrumentation and control (I\&C) system, and skid, cabinets and ventilation. Over the 10 year Cooperative Agreement, significant cost reductions and technology advancements were made in the air supply system, purge gas system and fuel desulfurizer as described in the following paragraphs. In addition, significant know-how was developed in modifying and integrating stand-alone gas turbine generators into pressurized hybrid systems. This is also described below.

\section{Air Supply System}

The EDB/ELSAM $100 \mathrm{kWe}$ Combined Heat and Power System (CHP-100), the OPG $250 \mathrm{kWe}$ Combined Heat and Power System (CHP-250) and the Stadtwerke Hannover $125 \mathrm{kWe}$ Combined Heat and Power System (CHP-125) were all atmospheric pressure units producing grid connected power and hot water. For the CHP-100 and CHP-250 units, the major components of the air supply system were the air blower, air/exhaust recuperator, startup air heater and high temperature air and exhaust piping. The air/exhaust recuperator receives SOFC exhaust gas at $800-850^{\circ} \mathrm{C}$ and produces approximately $600^{\circ} \mathrm{C}$ air in steady state. Due to these high temperatures and extensive heat transfer surface area ( $70 \%$ effectiveness), the recuperator is the second most expensive component $(\$ 1,000 / \mathrm{kWe})$ in the BOP. (PCS is the most expensive.) The CHP-125 relocated the recuperator and startup heater inside the SOFC module by increasing the air feed tube (AFT) length by $41 \mathrm{~cm}$ and containing the AFTs within 48 ceramic housings ( 1 housing per cell bundle) in a section above the combustion zone. These housings force the stack exhaust gas to flow in annular channels surrounding the AFTs in a counter-flow arrangement, which produces the desired exhaust-to-air heat transfer. If the startup air heater is on the air side, the heat must be located at or downstream of the recuperator air outlet in order to deliver most of the heater thermal power to the cell stack. So pencil-type air heaters were located inside the AFT's (1 heater per AFT) at the recuperator air outlet. These module design changes result in the elimination of the air/exhaust recuperator, startup air heater and high temperature air/exhaust piping from the BOP but increased the complexity of the SOFC module. It turned out that the pencil-type air heater system was too expensive and not sufficiently reliable. (See section 8.0, CHP-125.) The internal AFT recuperator concept is an important cost reduction feature but a different startup heater concept is needed. Under the SECA Coal-Based Hybrid program, fuel side startup heating is being studied.

\section{Purge Gas System}

All the field units, excluding the $5 \mathrm{kWe}$ units, utilized a $5 \% \mathrm{H}_{2}$ in $\mathrm{N}_{2}$ gas mixture as the purge gas. Purge gas prevents oxidation of nickel components on the fuel side above $400^{\circ} \mathrm{C}$ when the fuel flow to the cell stack is shut off. This pre-mixed gas, referred to as NHMIX, is very expensive, costing about $\$ 8,000$ per startup and shutdown cycle for the CHP-125. So effort was expended on developing a purge gas system to replace the NHMIX system. The SteamEthanol Purge System (SEPS) was the result of this development effort. Ethanol $\left(\mathrm{C}_{2} \mathrm{H}_{5} \mathrm{OH}\right)$ is added to water in the concentration $18 \mathrm{~mole} \%$ ethanol. The mixture is vaporized by electrical heaters before being delivered to the SOFC generator. The ethanol cost per startup and shutdown cycle for the CHP-125 is $\$ 400$ compared to $\$ 8,000$ for NHMIX. SEPS was successfully tested in a $5 \mathrm{kWe}$ system and a full scale SEPS for the CHP-125 was built and successfully "bench" tested. This SEPS was intended for the second CHP-125 unit, which will not be built and tested. 


\section{Fuel Desulfurizer}

The CHP-100, $\mathrm{PH}-220$ and $\mathrm{PH}-300$ used activated carbon as the adsorbent for the removal of sulfur compounds from natural gas. It was necessary to change out the adsorbent very frequently (e.g., every 6 weeks for the CHP-100) in order to avoid stack voltage degradation. The CHP-250 used an expensive, experimental zeolite material as the adsorbent. Neither of these materials are a satisfactory solution for natural gas desulfurization; activated carbon because of its ineffectiveness in removing certain sulfur compounds and the experimental zeolite because of its expense.

In the year 2000 Siemens began a testing program to identify a cost effective sorbent for the removal of sulfur compounds from natural gas. The test program has proceeded at varying levels of effort until 2007 and 7 different materials were tested. Sulfatrap ${ }^{\text {TM }}$ R3 by TDA Research, Inc. was selected as the preferred desulfurizer adsorbent. This material was successfully tested in three $5 \mathrm{kWe}$ units and in the CHP-125. Based upon test data, it is estimated that the TDA adsorbent replacement interval is about 3 years for the CHP-125.

\section{Pressurized Hybrid Technology}

The SCE 220 kWe Pressurized Hybrid Power System (PH-220) and the RWE 300 kWe Pressurized Hybrid Power System (PH-300) were combined cycle systems, producing electrical power from the pressurized SOFC module and the gas turbine generator. For pressurized hybrid systems, the air/exhaust recuperator must be located in the BOP so that high temperature $\left(800^{\circ} \mathrm{C}\right)$ SOFC module exhaust can first be delivered to the expander section of the gas turbine. Internal recuperator designs result in an SOFC module exhaust temperature of only $300^{\circ} \mathrm{C}$. The $\mathrm{PH}-220$, the world's first pressurized hybrid fuel cell power system, utilized a 2-stage recuperated microturbine generator (MTG). The first expander stage was the free spinning gasifier (turbine/compressor), which was the air mover. The second expander stage was the fixed speed power turbine, which drove the generator. With both the startup combustor and MTG combustor off, there was no direct means of modulating the gasifier air flow. Therefore, the SOFC module would heat up during the day and cool off during the night with a max.-to-min. stack temperature swing of $50^{\circ} \mathrm{C}$ due to gasifier air flow variation. The $\mathrm{PH}-300$ advanced the pressurized hybrid technology by utilizing a single stage, variable speed, recuperated MTG. The gas turbine and high speed alternator were on the same shaft. The high frequency $\mathrm{AC}$ power produced by the alternator was fed to a power conditioning unit which produced grid compatible voltage and frequency. The gas turbine speed could then be modulated by varying the electrical load on the alternator. This provided air flow control and, thus, stack temperature control.

\section{Conclusion}

The internal, air feed tube recuperator with net shape cast, ceramic housings should result in a significant power system cost reduction for CHP units due to the elimination of the expensive, high temperature alloy, external recuperator and associated piping. A reliable and cost effective startup heating system still needs to be developed. For pressurized hybrid systems, a government funded hybrid gas turbine development program is most likely needed in order to successfully commercialize pressurized hybrid systems. 


\subsection{Automated Manufacturing Facility (Task 6)}

In 2001, it was decided to proceed with the design and construction of a commercial manufacturing facility, called the Automated Manufacturing Facility (AMF). The existing manufacturing facility, called the Pilot Manufacturing Facility (PMF), had an insufficient manufacturing capacity ( 1 MWe per year) for commercialization. The design phase consisted of 1) preparing process specifications, manufacturing equipment bid specifications, and facility and equipment layout drawings, 2) obtaining equipment price quotations and construction cost estimates, 3) preparing commercial product cost estimates, and 4) evaluating potential sites. In 2001 , it was decided to begin the construction of a $200,000 \mathrm{ft}^{2}$ AMF in Munhall, Pennsylvania. This facility was sized for 15 MWe per year manufacturing capacity. (Phase 2 construction would have expanded the manufacturing capacity to 200 MWe per year.) The building was completed in 2002 but, shortly thereafter, it was decided not to proceed with commercialization at that time. The reasons for this decision were 1) operating problems with the CHP-250 and $\mathrm{PH}-300,2)$ slow progress on the development of the electrolyte APS and fuel electrode APS process, and 3) lack of a sufficiently low cost commercial product design. In hindsight, this was the correct decision since R\&D to reduce product cost is still continuing. A photograph of the AMF is presented in Figure 6-1.

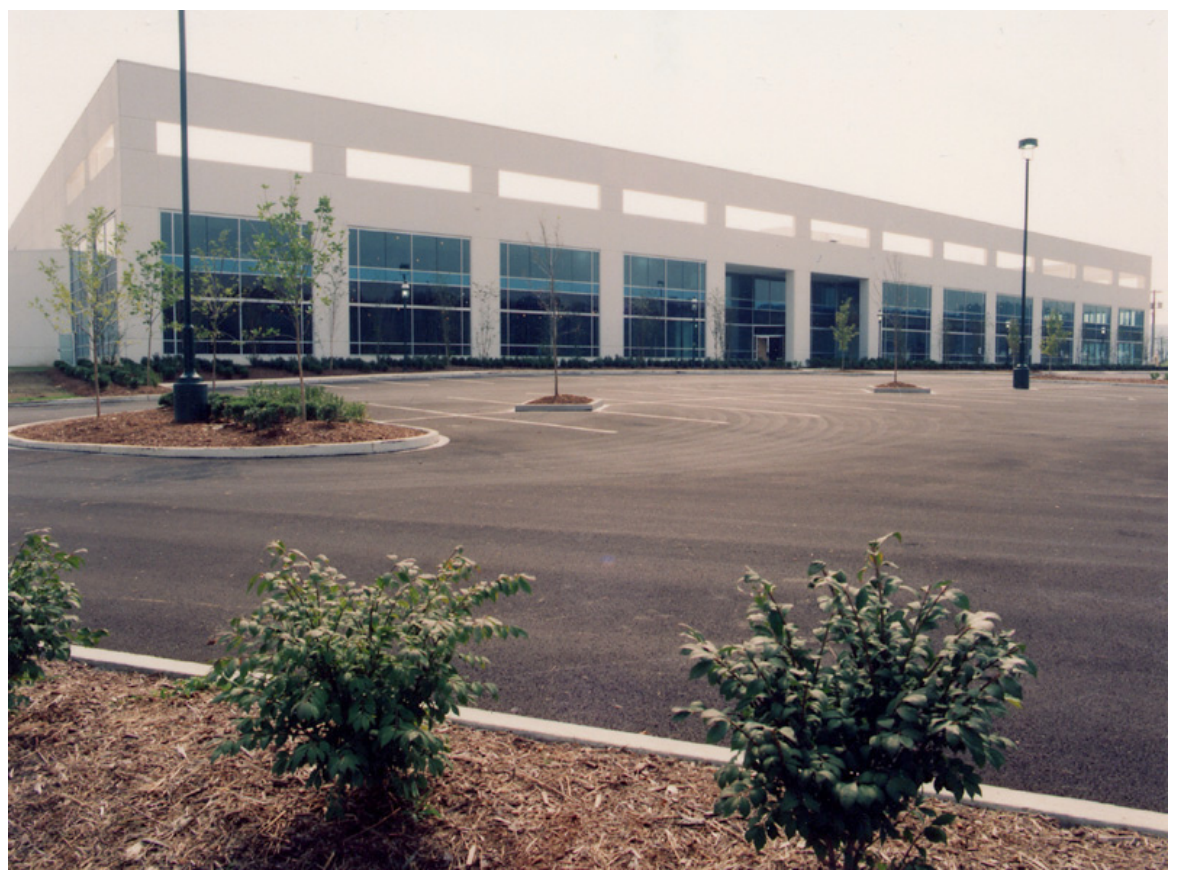

Figure 6-1 - Photograph of Building Intended for Automated Manufacturing Facility

\section{Conclusion}

Since the product cost targets have not yet been met, it was the right decision to delay commercialization and stop work on the AMF. 


\subsection{EDB/ELSAM 100 kWe Power System Field Test (Task 7)}

The EDB/ELSAM $100 \mathrm{kWe}$ power system field test program was the most successful of all the field test programs and contributed the most to the advancement of tubular SOFC technology. A photograph of the unit installed at the customer's site in Westervoort, The Netherlands is shown in Figure 7-1. The contract with EDB/ELSAM (a consortium of Dutch and Danish utilities) was signed on December 19, 1994 for the delivery of a natural gas fueled $100 \mathrm{kWe}$ combined heat and power system (CHP-100) containing many first-of-kind design features.

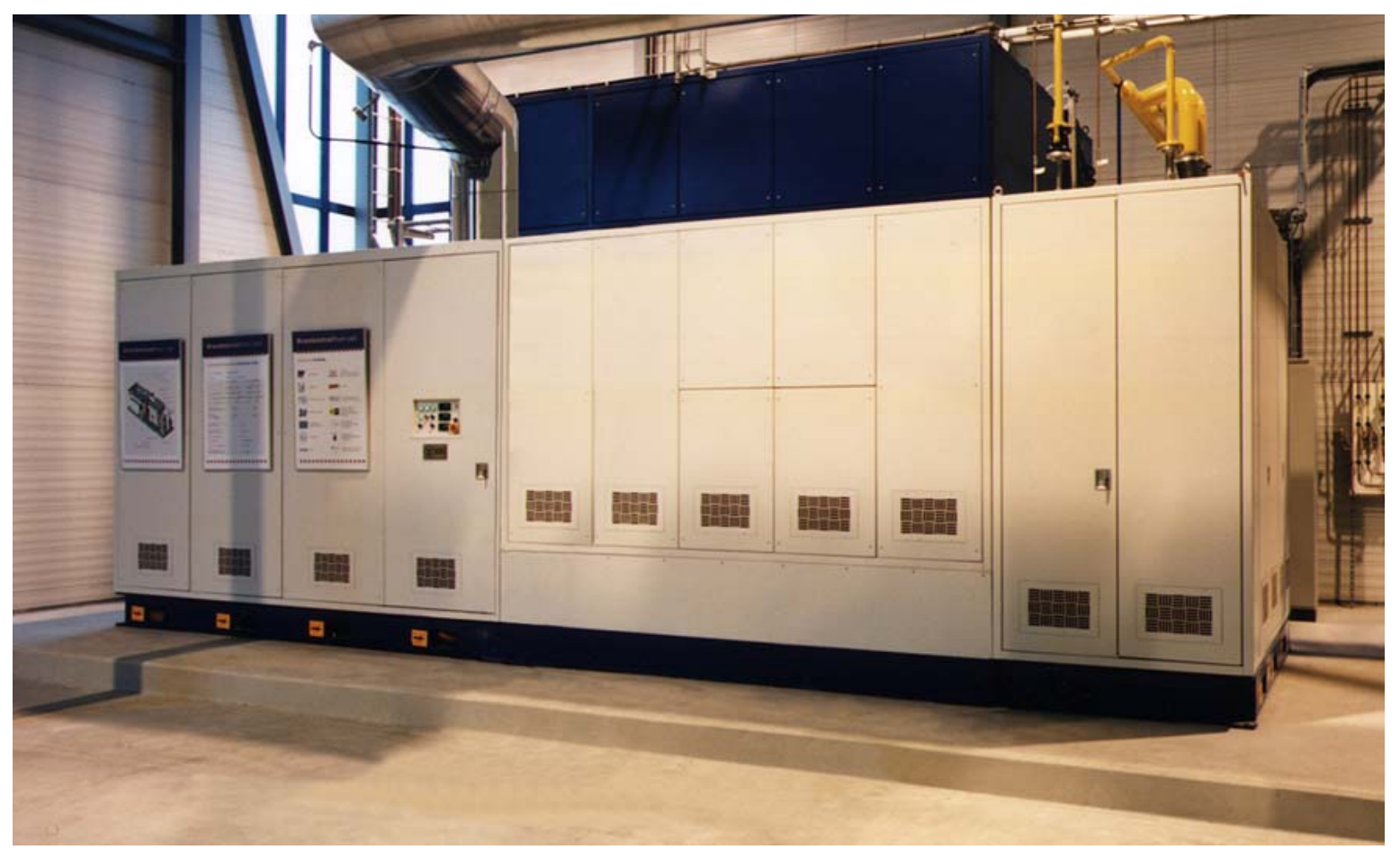

Figure 7-1 - Photograph of the EDB/ELSAM 100 kWe Power System

The cell stack was comprised of 1152, $150 \mathrm{~cm}$ active length, air electrode supported cells divided into 12 bundle rows of 96 cells each. Stack reformers were located between the bundle rows and outboard of the peripheral bundle rows (rows 1 and 12) as shown in Figure 7-2. These stack reformers received radiant heat from the adjacent bundle rows and fully reformed the incoming natural gas into $\mathrm{H}_{2}$ and $\mathrm{CO}$ prior to delivery to the cells. The incoming natural gas was first humidified by recirculation of a portion of the depleted fuel exiting the stack $(80 \%$ $\mathrm{H}_{2} \mathrm{O} / \mathrm{CO}_{2}$ and $20 \% \mathrm{H}_{2} / \mathrm{CO}$ ) using fuel ejectors. The humidified natural gas then entered an adiabatic pre-reformer to reform the higher hydrocarbons $\left(\mathrm{C}_{2} \mathrm{H}_{6}\right.$ and higher) prior to entering the stack reformers. Figure 7-3 presents the fuel-side flow paths within the SOFC generator. The above technology features $(150 \mathrm{~cm}$ air electrode supported cells, stack reformers, depleted fuel recirculation with fuel ejectors, and pre-reformer) formed the cell stack design basis for all the subsequent field test units discussed in Section 8. 


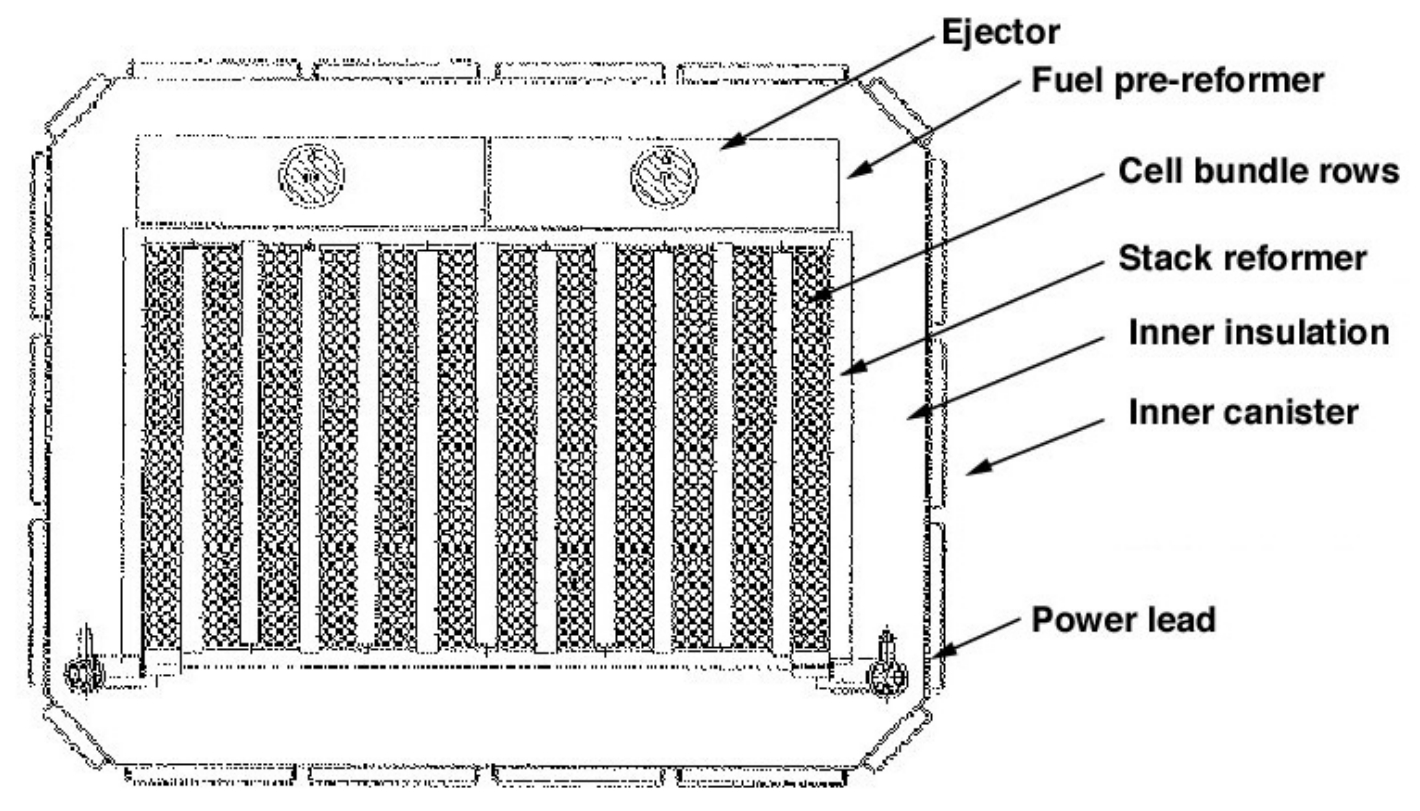

Figure 7-2 - Cross Section of 100 kWe Cell Stack

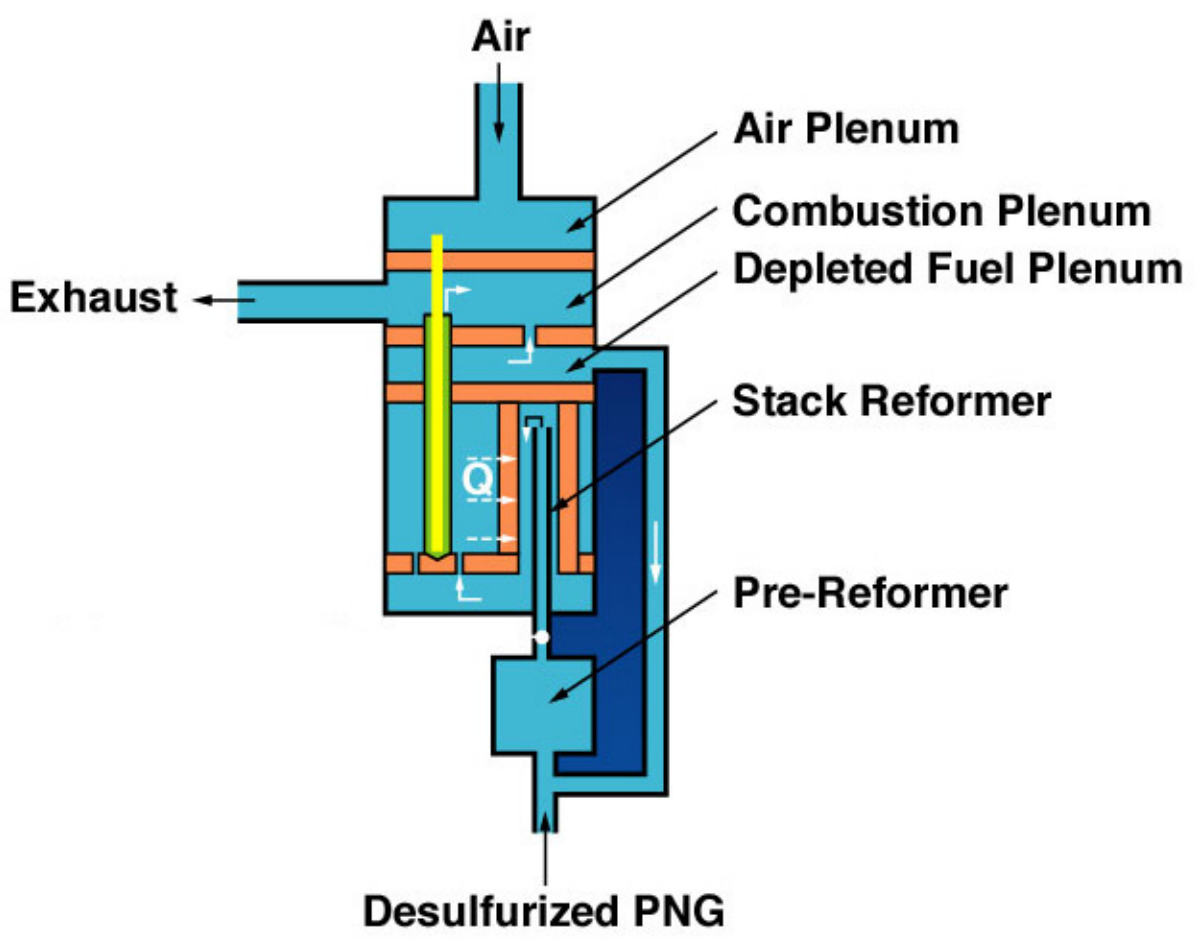

Figure 7-3 - Fuel Side Flow Paths within the 100 kWe Generator 
The Factory Acceptance Test (FAT) was performed in October 1997 (335 operating hours) and the unit was tested at the customer's site in Westervoort, The Netherlands from December 1997 thru June 1998 (3700 operating hours) achieving $105 \mathrm{kWe}$ net AC at 43\% electrical efficiency. The unit was shutdown in late June due to a declining voltage in one of the bundle rows. It was then decided to return the SOFC generator to Pittsburgh for post-test inspection and repair, as necessary. The post-test inspection revealed broken upper positioning boards, oxidation of cell anodes and nickel felts, felt separation, and some cracked cells at bundle ends (adjacent to bundle weld plates). The root cause was determined to be the broken upper positioning boards, which form the boundary between the exhaust (15\% oxygen) and the recirculated, depleted fuel. These broken boards allowed some of the exhaust to enter the recirculation plenum and be recirculated. This was the cause of the lower than expected stack performance, declining bundle row voltage, and observed nickel oxidation.

Since the warranted operating period was 2 years, it was decided to replace all the cells with new cells. In addition, the following design improvements were made: cell-to-cell spacers within bundles, laser mapping of cell open end positions in bundles and custom drilling of upper positioning boards, ceramic cloth reinforced upper positioning boards, and the addition of a metallic stack liner. The rebuilt SOFC generator (Build 2) was re-installed at the customer's site and the field unit was restarted in March 1999. The system performance was much improved, producing $110 \mathrm{kWe}$ net $\mathrm{AC}$ at $46 \%$ electrical efficiency. The unit operated for 12,600 hours with no measurable voltage degradation, completing its warranted operating period (4000 hours for build 1 generator and 12,600 hours for build 2 ).

The unit was shutdown at the end of contract in November 2000. It was later moved to Essen, Germany at an RWE site for further testing. The unit was restarted in June 2001 and operated for another 3900 hours before an automatic shutdown occurred on January 30, 2002 due to low terminal voltage, caused by cell cracking and electrical connection separation in bundle row 10 .

Following the January 30, 2002 shutdown, the unit was returned to Pittsburgh for post-test inspection. It was determined that the low bundle row 10 voltage was due to badly damaged cells adjacent to bundle-to-bundle weld plates with associated heavy nickel oxidation and loss of electrical connection. The root cause of the failure was determined to be a combination of low stability interconnection (low A/B ratio), local operating temperature above $1000^{\circ} \mathrm{C}$, and cell mechanical stress associated with weld plates.

In 2004, an agreement was reached with an Italian customer (GTT) to refurbish the unit for operation in Torino, Italy. The refurbished module (build 3 module) contained 22 bundles (528 cells) from the build 2 module (16,500 operating hours) and 26 new bundles (624 new cells). The refurbishment was completed in March, 2005 and the unit startup in Italy occurred in June, 2005. The unit operated for an additional 16,400 hours before the field unit test came to an end on June 8, 2007 due to a low bundle row voltage.

\section{Conclusion}

The operating history of the CHP-100 field unit in The Netherlands, Germany and Italy clearly demonstrated the long term durability and stability of the tubular SOFC technology, including cells, stack reformers, pre-reformer, fuel ejectors, air feed tubes, etc. A total of $528,150 \mathrm{~cm}$ active length, air electrode supported cells operated for a total of nearly 33,000 hours (build 2 plus build 3 ). Table 7-1 summarizes the CHP-100 operating history. 
Table 7-1

Summary of CHP-100 Operating History

\begin{tabular}{|c|c|c|c|}
\hline $\begin{array}{c}\text { SOFC Generator } \\
\text { Build }\end{array}$ & Site & Operating Hours & Thermal Cycle $^{(1)}$ \\
\hline 1 & Pittsburgh & 300 & 1 \\
\hline 1 & $\begin{array}{c}\text { Westervoort, } \\
\text { The Netherlands } \\
\text { Westervoort, } \\
\text { The Netherlands }\end{array}$ & 3700 & 2 \\
\hline 2 & Essen, Germany & 12,600 & 7 \\
\hline 2 & Turin, Italy & 16,900 & 2 \\
\hline 3 & & 16,410 & 8 \\
\hline
\end{tabular}

(1) $1000^{\circ} \mathrm{C}-\mathrm{RT}-1000^{\circ} \mathrm{C}$ or RT- $1000^{\circ} \mathrm{C}-\mathrm{RT}$ 


\subsection{Other SOFC Power System Field Tests (Task 8)}

This section describes the field unit test programs other than the EDB/ELSAM $100 \mathrm{kWe}$ Power System, which is described in Section 7 . These field units are categorized as either combined heat and power (CHP) or pressurized hybrid $(\mathrm{PH})$. A CHP system is characterized by an atmospheric pressure SOFC generator, an exhaust-to-air heat exchanger (recuperator), an air blower, and a heat export system (HES), generally for hot water production. Figure 8-1a presents a simplified flow schematic of a CHP system. A PH system is characterized by a pressurized SOFC generator and a recuperated gas turbine generator. Figure 8-1b presents a simplified flow schematic of a $\mathrm{PH}$ system.

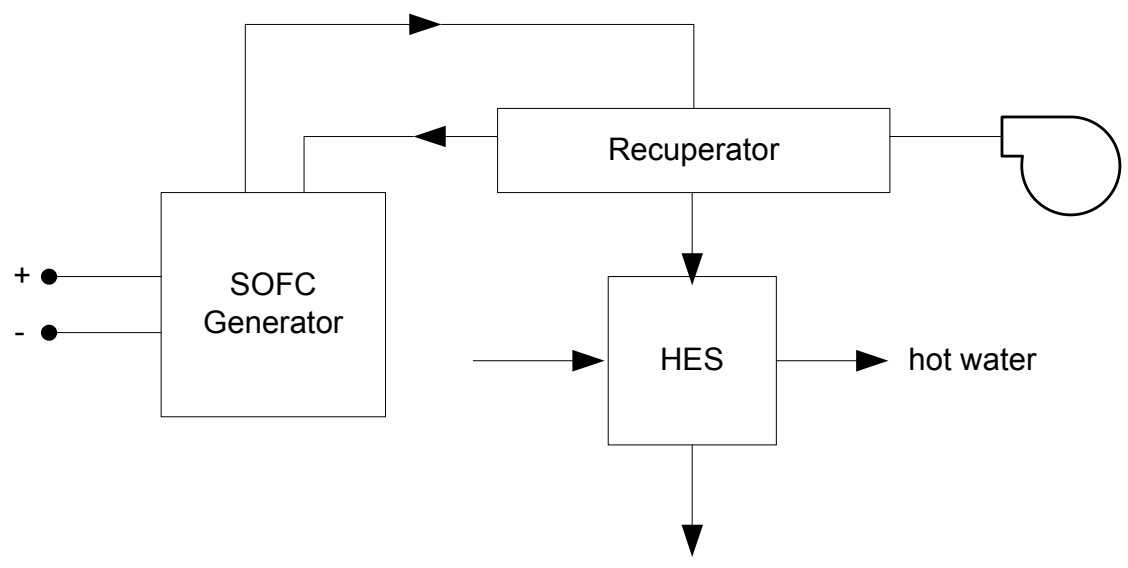

Figure 8-1a - CHP System Simplified Flow Schematic

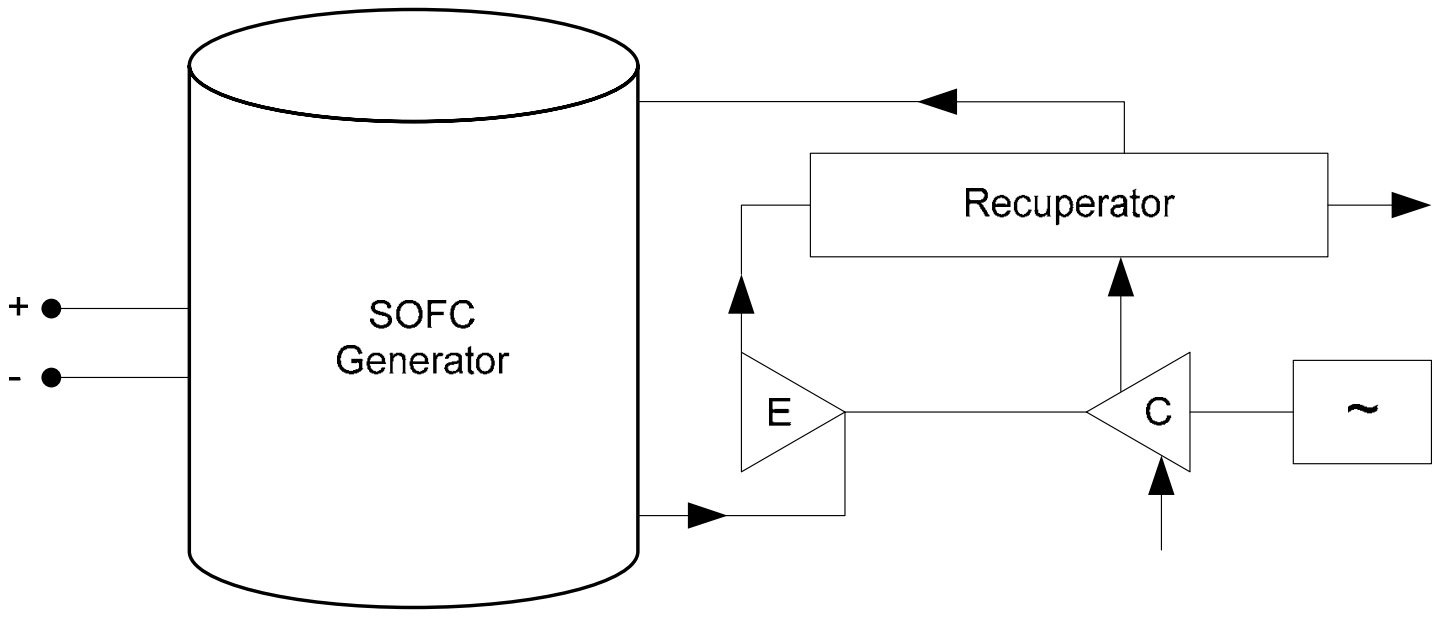

Figure 8-1b - PH System Simplified Flow Schematic

The field unit test programs are discussed in the following order:

PH-220 (Pressurized Hybrid - 220 kWe)

CHP-250

$\mathrm{PH}-300$

CHP-125 


\section{PH-220}

The world's first power system that combined a pressurized SOFC generator with a gas turbine generator was the PH-220 sponsored by Southern California Edison (SCE) and the United States Department of Energy (DOE). A simplified process flow diagram for the $\mathrm{PH}-220$ system is shown in Figure 8-2. A photograph of the fully assembled unit is shown in Figure 8-3 and an isometric drawing of the system is shown in Figure 8-4. The pressurized SOFC generator consisted of the $100 \mathrm{kWe}$ generator stack design contained within a pressure vessel. The gas turbine was a $70 \mathrm{kWe}$, two-shaft (gasifier and power turbine), recuperated microturbine generator (MTG) manufactured by Ingersol Rand Energy Systems, operating in a de-rated condition. There was no MTG that matched the air flow requirements of the SOFC generator; therefore, this MTG was selected and adapted even though it was approximately $50 \%$ oversized in design air flow. The contract with SCE was signed on July 1, 1997. The design, manufacturing and shakedown phases were completed by March 2000. The operating history is discussed in the following paragraphs.

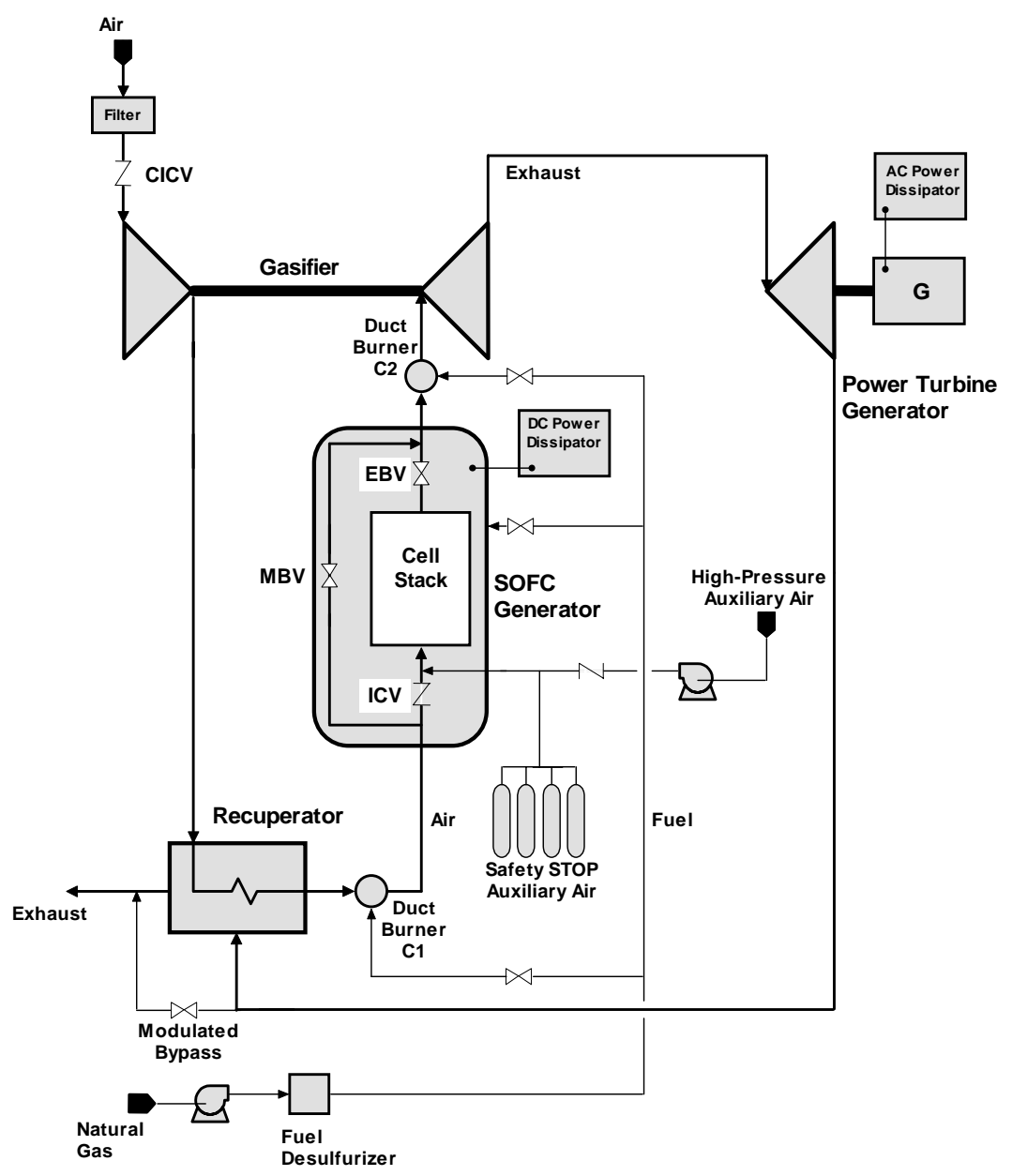

Figure 8-2 - PH-220 Simplified Process Flow Diagram 


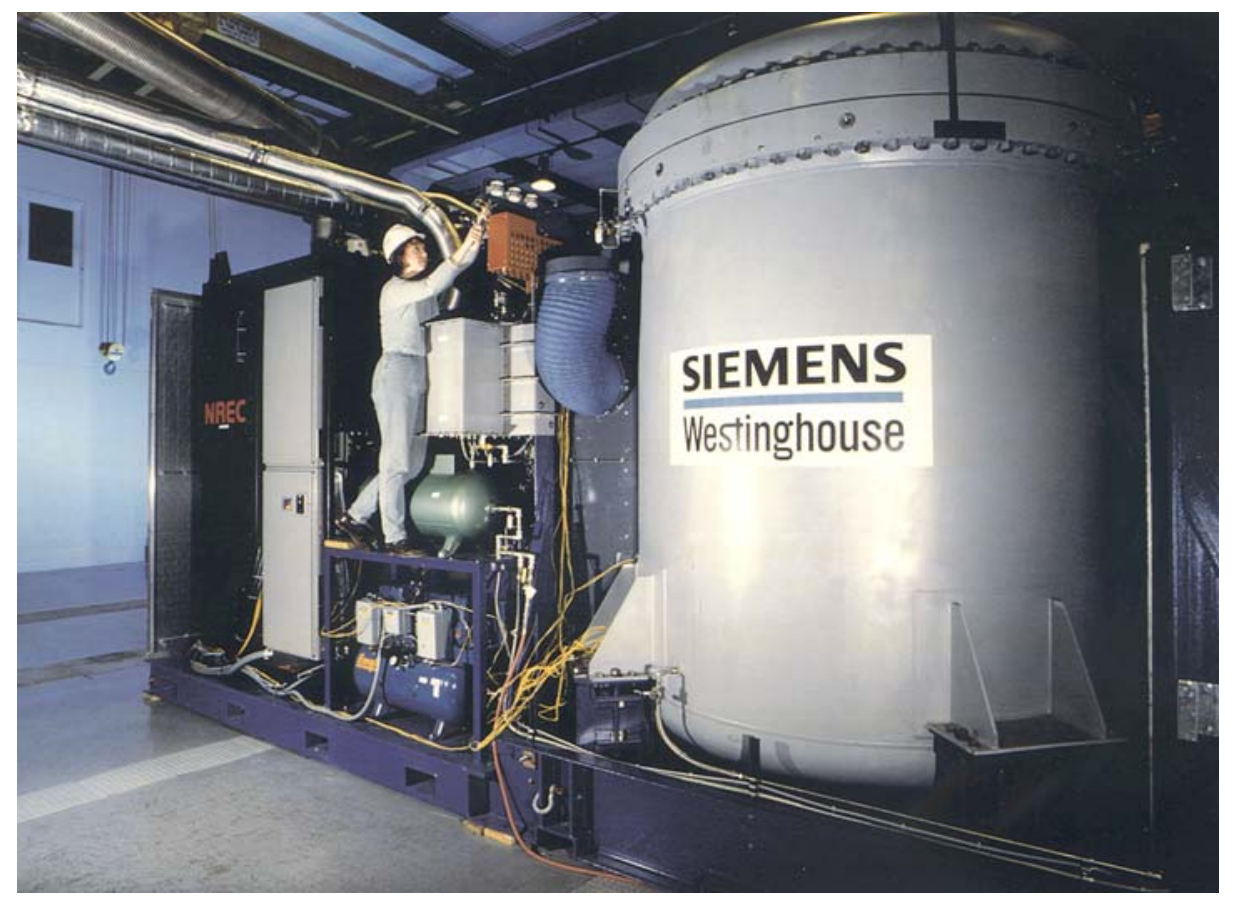

Figure 8-3 - Photograph of the SCE PH-220 Power System

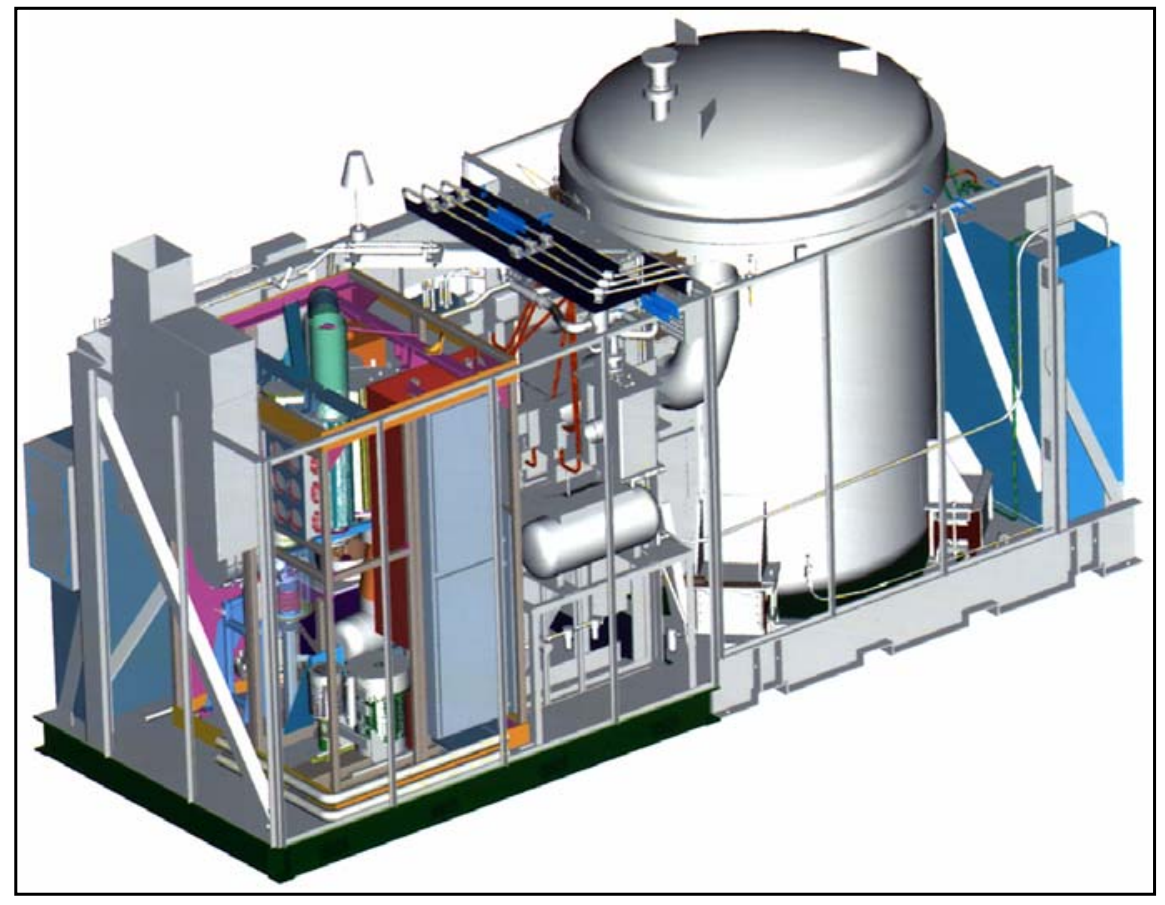

Figure 8-4 - Isometric Drawing of the SCE PH-220 Power System 
Originally, the $\mathrm{PH}-220$ cell stack was to consist of only new cells. However, many of the cells intended for the PH-220 were diverted to build 2 of the EDB/ELSAM $100 \mathrm{kWe}$ cell stack, resulting in insufficient new cells (486 out of 1152) for the PH-220. Since the PH-220 was more of a system Proof-of-Concept test than a cell stack endurance test, it was decided to use some of the used cells from build 1 of the EDB/ELSAM $100 \mathrm{kWe}$ cell stack. The anodes of these used cells were partially oxidized during the final shutdown of the $100 \mathrm{kWe}$, build 1 cell stack.

The Factory Acceptance Test (FAT) was conducted in April 2000 for 110 hours. The hybrid power system successfully operated with both combustors off (C1: startup combustor, C2: MTG combustor), producing $166 \mathrm{kWe}$ DC (no DC-to-AC inverter) from the pressurized SOFC generator and $22 \mathrm{kWe}$ AC from the MTG. Under the assumption of a $92 \%$ power conditioning system efficiency, the electrical efficiency was calculated to be slightly above $50 \%$ (net AC/LHV). The total power output and system efficiency was lower than the design values for two reasons: 1) higher than expected MTG air flow resulted in a lower than expected turbine inlet temperature and lower than expected MTG power output, and 2) about $3 \%$ of the incoming fuel was bypassing the cell stack based upon gas chromatography analysis.

Following the successful FAT, the unit was then transported to the customer's site at the University of California, Irvine ( $\mathrm{UCl})$ campus and the site test began in June 2000. The unit operated for 154 hours before an automatic shutdown occurred on low terminal voltage. Since the stack voltage was stable at its normal value at the time of the shutdown, it was inferred that the low terminal voltage was due to a problem with one or both of the power leads, which conduct direct current in and out of the SOFC generator. The SOFC generator was returned to Pittsburgh in July 2000 for inspection and repair. Inspection of both power leads revealed 1) missing insulation around both power lead housings, which resulted in fuel bypass and burning around the housings, and 2) melting of a brazed joint between a rigid nickel connector and a nickel clad copper cable in the negative power lead, which broke the current path. The two power lead housings, which contain these brazed joints and nickel clad copper cables, were moved to a higher, cooler elevation and the housings were well insulated.

Following the first repair, the SOFC generator (build 2) was returned to $\mathrm{UCl}$ and the system was restarted in January 2001. This time, the system achieved a power output of $170 \mathrm{kWe}$ DC from the SOFC generator and $20 \mathrm{kWe}$ AC from the MTG at a calculated electrical efficiency of $52 \%$ (net AC/LHV). The efficiency improvement is attributed to the elimination of fuel bypass around the power lead housings. The system operated for 514 hours until the system was manually shutdown on February 12, 2001 due to low bundle row 2 voltage. The SOFC generator was returned to Pittsburgh for a second time for inspection and repair.

The results of the inspection program are summarized below:

- A cracked cell (EDB/ELSAM build 1 cell) was found in bundle row 2.

- The stack liner was badly wrinkled and torn in many places.

- The power leads were in good condition confirming the design fix was effective.

It was then decided to reduce the number of EDB/ELSAM build 1 cells in the stack because they were judged to be of higher risk. The new stack consisted of 179 EDB/ELSAM build 1 cells (down from 666), 421 original cells with NGK AE tubes (down from 486) and 552 new cells with Siemens $A E$ tubes. In addition, the stack liner was redesigned to be more resistant to tearing.

The SOFC generator (build 3) was returned to the UCl site in November 2001 but a problem with the MTG prevented the unit startup. Following the MTG fix, the PH-220 was restarted on February 1, 2002 and operated until April 7, 2002 (1322 hours). On April 7, the unit automatically shutdown on low terminal voltage, caused by a very low bundle row 11 voltage 
(new cells with Siemens $A E$ tubes). The best performance in terms of power output and stability was achieved during this operating period. The SOFC generator achieved a peak power of 175 kWe DC and the MTG produced $18 \mathrm{kWe}$ AC. The SOFC generator was returned to Pittsburgh for a third time for inspection and repair.

Stack inspection revealed major damage in bundle row 11, which consisted of new cells with Siemens AE tubes. These cells had a slightly smaller diameter than the cells with NGK AE tubes. The smaller diameter led to a bigger diametral clearance between the cell O.D. and the upper positioning board thru which the cell open end passes. As a result, the depleted fuel flow rate entering the combustion zone was higher for these cells, which led to higher combustion zone temperatures, higher air inlet temperatures to these cells, and thus higher cell temperatures. These higher cell temperatures in combination with a less stable interconnection composition (excessive chromium oxide as a second phase) led to interconnection porosity development and eventual cell failure.

The SOFC generator repair consisted of 1) replacing damaged cells, 2) controlling the diametral gap between the cell O.D. and upper positioning board by custom hole drilling, and 3) replacing the deformed fuel distribution board under bundle row 12 with a new fiber board material (Rex Roto-15 pcf instead of ZAL-15 pcf). The SOFC generator (build 4) was returned to the UCl site in later October 2002.

The system restart occurred in November 2002 but, shortly thereafter, bundle row 11 voltage began to decline, which limited system power output. In January 2003, the unit automatically shutdown due to loss of power to the natural gas compressor. Shortly thereafter in a meeting between Siemens and SCE, it was agreed that the PH-220 field unit test had satisfied project objectives and that the technical viability of the pressurized hybrid concept had been proven. The unit operated for an additional 1156 hours. The PH-220 unit was returned to Pittsburgh for final inspection in December 2003. A cracked cell was found in bundle row 11 and the Rex Roto fuel distribution board under row 12 had broken, shifting fuel flow from row 11 to row 12 .

Table 8-1 summarizes the operating history of the $\mathrm{PH}-220$.

Table 8-1 - Summary of PH-220 Operating History

\begin{tabular}{|c|c|c|c|}
\hline Operating Period & $\begin{array}{c}\text { SOFC Generator } \\
\text { Build }\end{array}$ & Operating Hours & Comments \\
\hline April 2000 & 1 & 110 & FAT \\
\hline June 2000 & 1 & 154 & Failed Power Lead \\
\hline Jan./Feb. 2001 & 2 & 514 & Cell Damage in Row 2 \\
\hline Feb. $\rightarrow$ April 2002 & 3 & 1322 & Cell Damage in Row 11 \\
\hline Nov. 2002 $\rightarrow$ Jan. 2003 & 4 & 1156 & Cell Damage in Row 11 \\
\hline
\end{tabular}

\section{Conclusion}

The PH-220 was the world's first test of a pressurized, high temperature fuel cell generator coupled to a gas turbine generator. The technical viability of the pressurized hybrid concept was clearly demonstrated. The $\mathrm{PH}-220$ operated for a short time with both combustors off and achieved a calculated electrical efficiency of $52 \%$ (net AC/LHV), a world record for a fuel cell power system on natural gas. Even though there were a number of failures within the SOFC generator. These have nothing to do with pressurized operation. The failures were directly related to cell/module design deficiency or quality control issues. 


\section{CHP-250}

The natural gas fueled CHP-250 field unit development program was a collaborative effort between Siemens and Kinectrics (formerly Ontario Hydro Technologies) under the sponsorship of the U.S. DOE, the Canadian government, and Ontario Power Generation. The module design and build was the responsibility of Siemens, the BOP design was a collaborative effort, and the BOP build was the responsibility of Kinectrics. The unit was designed to produce 233 kWe net AC at an electrical efficiency of $47 \%$ (net AC/LHV), and $139 \mathrm{kWt}$ in the form of hot water. The unit contained many unique design features intended to advance the state-of-the-art in SOFC technology, namely:

- Largest cell stack design, 2292 cells

- Open air inlet plenum, eliminating expensive, high temperature air inlet boxes

- Power lead design without forced air cooling

- Ceramic side exhaust ducts

- Natural gas fired startup heater.

A photograph of the fully assembled system installed at the customer's site is shown in Figure 8-5. The contract was signed on April 7, 2000 and the design, build and shakedown phases were completed by October 2002, $2 \frac{1}{2}$ years later. The operating history is discussed below.

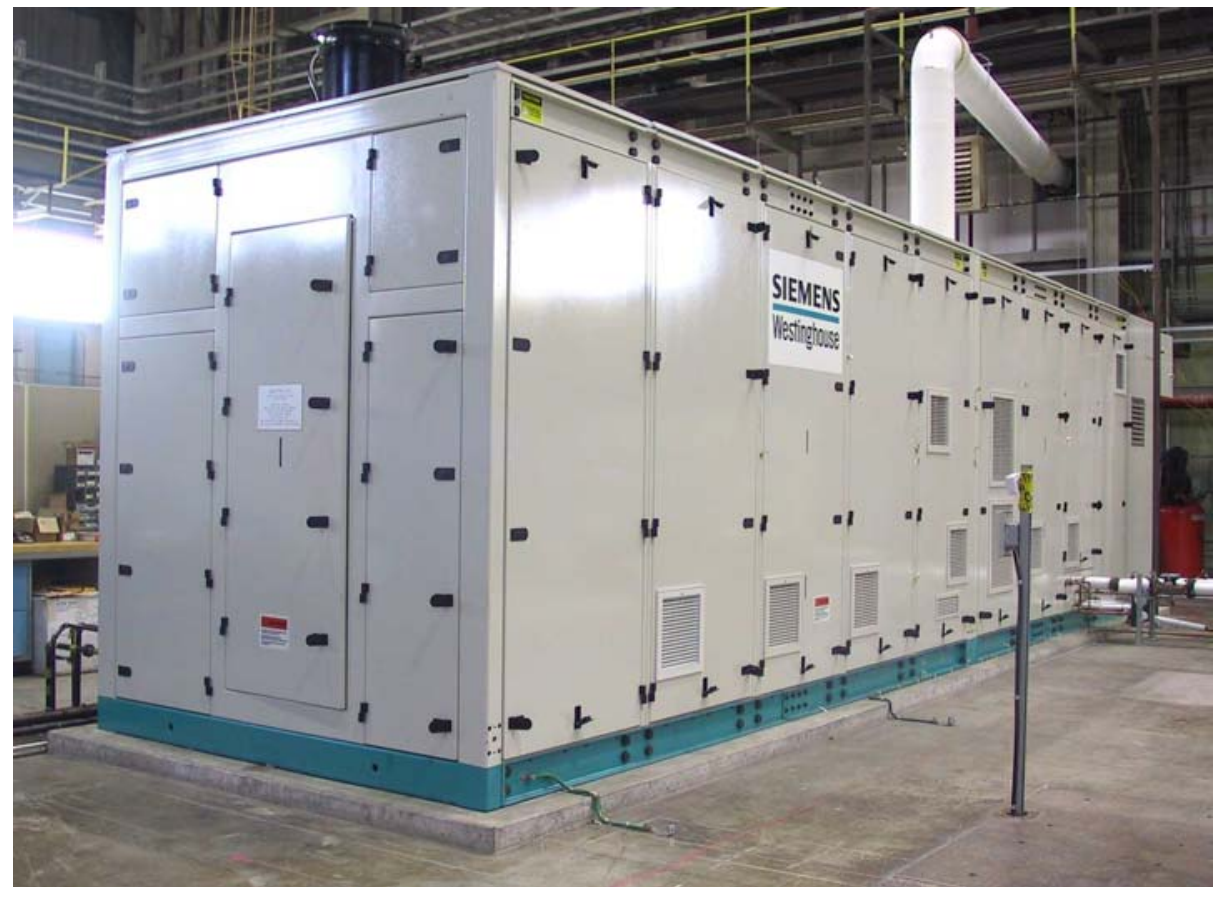

Figure 8-5 - Photograph of the OPG CHP-250 Power System

Due to the nature of the collaborative agreement with the SOFC generator being assembled at the Siemens facility in Pittsburgh and the BOP being assembled at the Kinectrics facility in Toronto, a Factory Acceptance Test was not performed. The SOFC generator was transported to the Toronto site for integration with the BOP in August 2002 and the system heat-up was initiated on October 12, 2002. Two problems were encountered during the heat-up that were both due to over-heating: 1) failure of an elastomer seal on the side of the gas-fired air heater and 2) shorting of stack instrumentation wires. The air heater seal was redesigned and the 
upper head insulation package was also redesigned to better protect the instrumentation wires from overheating. The repairs were made and the re-start began on April 1, 2003.

The unit operated intermittently over the time period from April 1 through June 23, 2003 when a PCS fault caused the unit to shutdown. During that period, the unit experienced 3 shutdown events including the June 23 shutdown, operated in RUN for 1130 hours, and achieved a peak power output of $193 \mathrm{kWe}$ net AC at an electrical efficiency of 38\%. After several unsuccessful restart attempts and the observation of high temperatures and shorting in bundle row 24, it was decided to shutdown the unit for post-test inspection. The SOFC generator was then returned to Pittsburgh where the post-test inspection took place.

Detailed stack inspection revealed 21 broken cells in rows 23 and 24 at the recirculation zone elevation adjacent to the ejector inlet, and another 97 cells with broken open ends. Concerning the recirculation zone failures in rows 23 and 24, it was hypothesized that high pressure air from the non-sealed air inlet plenum (first of a kind design) leaked down thru peripheral insulation until it found the lower pressure ejector inlet. At this location combustion between the leakage air and anode recirculation gas occurred causing the cells in rows 23 and 24 to crack. The hypothesized open end failure mechanism is different. During the attempted restart following the June 23, 2003 shutdown, the stack could not be loaded due to a PCS problem but fuel was being fed to the SOFC generator. This unreacted fuel entered the combustion zone and combusted with the air exiting the cells, stressing the cell open ends. The maximum combustion zone temperature reached $1067^{\circ} \mathrm{C}$ during the attempted restart.

Given the extensive redesign and repair required, it was agreed by the Parties to end this test and apply the lessons learned to future designs.

\section{Conclusion}

This was the first SOFC generator to have a single, non-sealed air inlet plenum, the boundary of which was defined by ceramic plates. (Previous designs utilized sealed Inconel air inlet boxes, which were very expensive.) This design deficiency led to the cell failures in the recirculation zone. Future designs will ensure that high pressure inlet air cannot find its way to the lower pressure ejector inlet. It was also determined that the fuel/air ratio in the combustion zone and combustion zone temperatures exceeded our experience base. This high fuel/air ratio was responsible for the cell open end failures. Limits will be put on the fuel/air ratio in the combustion zone and on combustion zone temperatures to ensure open end failures do not occur.

\section{$\mathrm{PH}-300$}

The $\mathrm{PH}-300$ was the world's second pressurized SOFC/gas turbine generator power system. The intended site was an RWE site in Essen, Germany. The pressurized SOFC generator consisted of a stack design 50\% larger than that of the PH-220 (1704 cells vs. 1152 cells) enclosed in a horizontal pressure vessel. Unfortunately, the air inlet plenum was not sealed from the fuel space, allowing air leakage into the fuel space. The gas turbine generator was a $100 \mathrm{kWe}$-class, single shaft, variable speed, recuperated microturbine generator (MTG) manufactured by ABB/Turbec. Figure 8-6 presents a photograph of the $\mathrm{PH}-300$ power system at the factory in Pittsburgh. The contract with RWE was signed on July 27, 2000. The design, manufacturing, and shakedown phases were completed by May 2003. The operating history is discussed in the following paragraphs. 


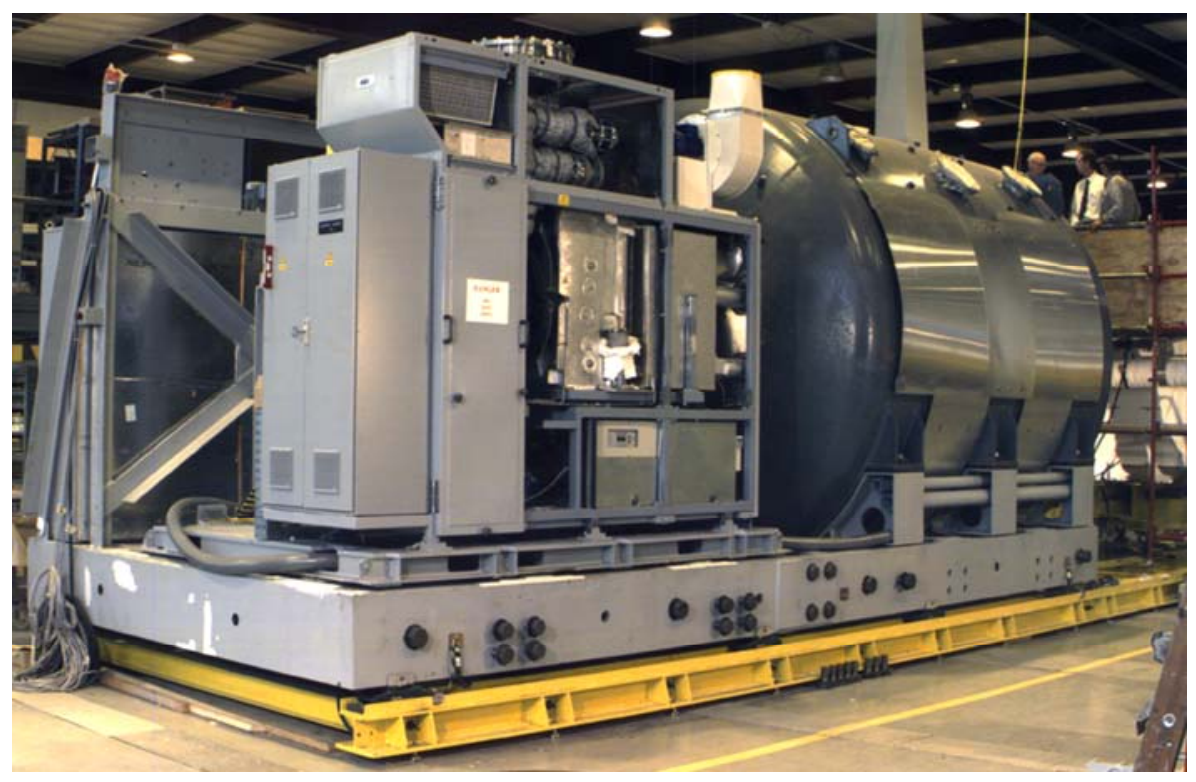

Figure 8-6 - Photograph of the RWE PH-300 Power System

The PH-300 Factory Acceptance Test (FAT) was conduced from June thru August 2003 and operated for only 479 hours. The FAT was terminated because the hybrid power system was not capable of achieving the warranted power output of $256 \mathrm{kWe}$ net AC. The maximum power output achieved was only $192 \mathrm{kWe}$ net AC with certain bundle row voltages below their low voltage limit. The lower than expected power output was attributed to air leakage from the air inlet plenum to the fuel space, similar to that experienced during the CHP-250 operation. Due to the extensive nature of the re-design and re-build, it was agreed with all stakeholders to terminate the project. Even though the FAT did not satisfy the acceptance criteria, it did validate some new and important design features as discussed below.

- MTG Air Flow Control: The ABB/Turbec MTG utilized a high frequency alternator plus power electronics to produce the desired AC voltage and frequency. This allowed the MTG speed, and thus air flow to the SOFC generator, to be modulated in order to control cell stack temperatures. This feature was not available on the $\mathrm{PH}-220$.

- Integrated Air Accumulator (IAA): An MTG fault results in loss of MTG air flow to the SOFC generator and depressurization of the SOFC generator. During depressurization, the pressurized fuel gas in the cell stack expands into the combustion zone. If there is insufficient air flow, cell open end damage will occur. The IAA is a very large air inlet plenum inside the SOFC pressure vessel, which delivers sufficient air flow to the cell stack during depressurization to prevent cell open end damage. The passive IAA eliminates the need for 1 or more active high pressure auxiliary air supply systems.

\section{Conclusion}

The PH-300 FAT exposed a major design deficiency in the SOFC generator and validated other design features important to the future of pressurized hybrid power systems. Leak paths existed between the higher pressure air inlet plenum and the lower pressure fuel space, resulting in air leakage into the fuel space, unintended consumption of fuel, loss of thermodynamic potential, and loss of power capability. In previous SOFC power system 
designs up to and including the $\mathrm{PH}-220$, the air inlet plenum design consisted of multiple Inconel air boxes that completely isolated inlet air from fuel. In the $\mathrm{PH}-300$, the air inlet plenum consisted of a large open space with ceramic plates forming the floor of the plenum. Post-test inspection revealed that these plates were susceptible to air leakage at plate edges and due to plate cracking.

\section{CHP-125}

The CHP-125 was originally envisioned to be a second generation CHP-250 but with 2 SOFC modules (125 kWe each) and 1 BOP. The BOP became very complicated with the added requirement that the need to shutdown and isolate one SOFC module should not affect the operation of the other SOFC module. It was subsequently decided to develop a CHP-125 power system (1 module and $1 \mathrm{BOP}$ ). If a customer desired a $250 \mathrm{kWe}$ unit, then two CHP-125 power systems would be provided.

The CHP-125 power system is the first unit with a rating above $5 \mathrm{kWe}$ to incorporate the following design innovations and cost reduction features:

- All-APS cells (1140 cells),

- $150 \mathrm{~cm}$ active length, $3 \times 8$ and $3 \times 7$, foam top screen bundles,

- Internal air feed tube recuperator,

- Cold, sealed SOFC air inlet boxes,

- Mullite air feed tubes,

- New recirculation zone design, and

- $3 / 4$ height stack reformer boards (SRBs).

The decision to relocate the air/exhaust recuperator from the BOP to inside the SOFC generator significantly reduced the cost of the BOP but required that the startup air heater also be located inside the SOFC generator near the recuperator air outlet. This was accomplished by using pencil-type electric heaters internal to the air feed tubes (one heater per AFT).

Since the air heaters are located inside the air feed tubes, there were no direct measurements of the air temperature exiting the air heater section. The average air temperature exiting the air heater section (THTRO) is computed from the following measured average parameters: air heater power, air flow, exhaust temperature at the recuperator inlet (average combustion zone temperature or $\mathrm{TCZ}$ ), exhaust temperature at the recuperator outlet, and air blower outlet temperature. In order to avoid damage to the air heaters, a limit of $850^{\circ} \mathrm{C}$ was placed on THTRO.

\section{Stadtwerke Hannover CHP-125}

In 2002, a contract was signed with Stadtwerke Hannover in Hannover, Germany for the delivery of the first CHP-125 unit. Figure 8-7 presents a photograph of the completed CHP-125 power system installed at the customer's site. The design, manufacture and shakedown phases were completed by June 2006. The unit's operating history is summarized below. 


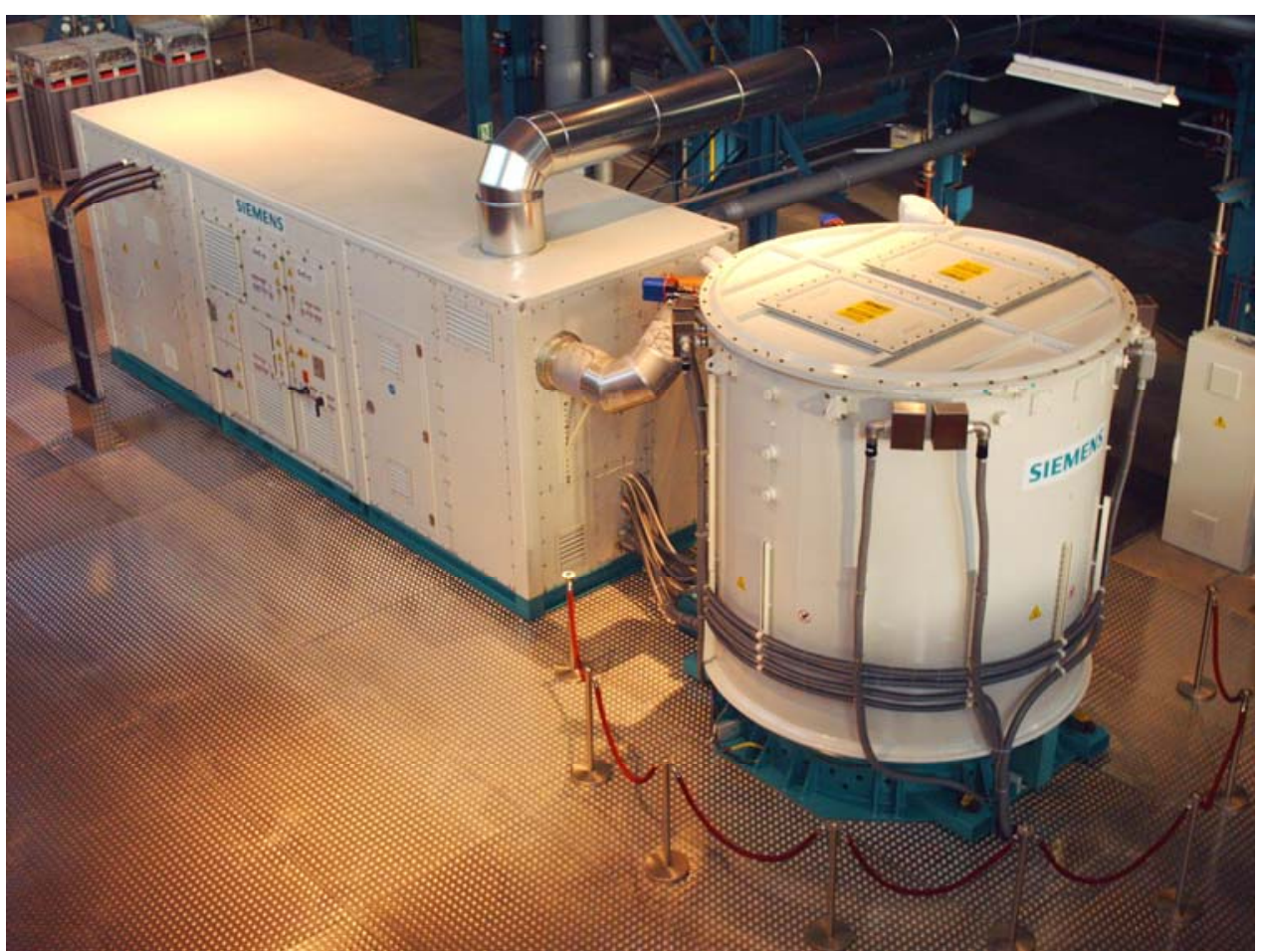

Figure 8-7 - Photograph of the Stadtwerke Hannover CHP-125 Power System

The Factory Acceptance Test (FAT) was conducted from June 21 thru July 27, 2006. The power system operated for 629 hours in the RUN state and experienced 6 STOP events, generally associated with equipment malfunctions, including the STOP event on July 27 (failure of flexible air duct) which ended the FAT. Just prior to the last STOP event, the unit achieved a power output of $100 \mathrm{kWe}$ net AC at an electrical efficiency of $40.7 \%$ (net AC/LHV) compared to the contract minimum performance requirements of $101.25 \mathrm{kWe}$ at $42.3 \%$ electrical efficiency. Some of the performance shortfall was due to a non-uniform temperature distribution across the stack (hot and cold bundles), which resulted in low voltage in the cold bundles. The temperature of the cold bundles could not be raised without the hot bundles exceeding their temperature limit. The cause of the non-uniform temperature distribution was determined to be non-uniform air flow distribution.

The cause of the non-uniform air flow distribution was unclear at the time of the FAT but, in hindsight, there were important clues from the FAT data and the post-FAT diagnostics. One very important post-FAT finding was that the actual air flow was $35 \%$ lower than the indicated air flow during the FAT. Using the lower air flows in the THTRO algorithm, resulted in the maximum THTRO increasing from $850^{\circ} \mathrm{C}$ (limit) to nearly $1000^{\circ} \mathrm{C}$. Since THTRO is an average temperature it became clear that hot cells had THTRO values considerably above $1000^{\circ} \mathrm{C}$. Nevertheless, except for a ground fault, which occurred and quickly cleared early in the FAT, there were no indications of air heater failure at the end of the FAT.

Following the FAT, some design modifications were made to flatten the stack temperature distribution, improve power output and electrical efficiency, and improve the air duct reliability. The unit was then shipped to Hannover, Germany for site testing in October, 2006. The site test began in December, 2006. The unit operated in RUN for 509 hours but the non-uniformity in stack temperature distribution (hot and cold bundles) and the power output/efficiency did not 
improve significantly. The unit automatically shut down on December 31, 2006 due to loss of PCS ventilation. A number of air heater failures occurred during the attempted restart, which prevented the cell stack from reaching its operating temperature. The SOFC generator was then returned to the factory for inspection and repair.

Post-test inspection revealed that 123 out of 1140 air heaters failed predominantly in the hot bundles. Excessive temperature was the root cause of heater failure. The air heater design consisted of a heating element surrounded by a crushed $\mathrm{MgO}$ dielectric enclosed in a metallic sheath, which is also the current return path. Heater failures were frequently accompanied by shorting to the sheath, blown fuses and multiple ground faults (shorting to ground) due to severe fuse damage. In severe cases, the sheath diameter expanded due to oxidation to such an extent that it became stuck inside the air feed tube, dramatically reducing air flow to the affected cell. It was also determined that there was a large variability in the as-built air feed tube I. D., relative to the diametral gap between the air heater O. D. and the air feed tube I. D. Smaller than average air feed tubes had smaller diametral gaps for air flow. This resulted in less air flow to the heater and cell, and higher heater and cell temperatures. Swelling of the overtemperature air heaters only made the problem worse.

In summary, the root cause of air heater failure in the hot bundles was air flows much lower than the design value. There were 3 major reasons for these low air flows: 1) incorrect blower air flow calibration during the FAT, which resulted in the actual air flow being $35 \%$ lower than the indicated air flow, 2) too much variability in air feed tube I. D., which resulted in low air flow bundles (hot bundles) and high air flow bundles (cold bundles), and 3) swelling of the overtemperature heaters, which only made the problem worse. The corrective action will be 1) an accurate air flow calibration, 2) tighter acceptance criterion for air feed tube I. D., and 3) a more robust air heater design, and 4) control software modifications.

\section{BP Alaska CHP-125}

A second CHP-125 system was scheduled for deployment in Alaska. This was a companion system, identified as the BP Alaska CHP-125, identical in design and function to the Stadtwerke Hannover (Hannover) system. Sponsored by DOE, BP America, Siemens, and an Alaskan consortium, this system was to have been built in series with the Hannover system. This was to allow for lessons learned in the build and operation of the Hannover system to be incorporated into the BP Alaska CHP-125.

Based on the experience of the Hannover CHP-125, the design and build of the BP Alaska CHP-15 was put on hold pending resolution of the design issues identified in the Hannover root cause analysis.

\section{Conclusion}

Even though the Stadtwerke Hannover CHP-125 field unit operated for only a relatively short time period ( 1100 hours), it did demonstrate the viability of the all-APS cells and foam-top screen bundles in large quantities. The internal air feed tube recuperator has promise as an important cost reduction feature but placing air heaters inside air feed tubes is not a good solution to startup heating. Fuel side heating may be a better solution for SOFC generators with internal recuperators and needs to be investigated. 


\subsection{Project Management (Task 9)}

The workscope under Project Management included writing of annual reports and field unit topical reports, and performing and documenting due diligence power system cost studies. The cost models were developed with the support and oversight of A. D. Little and Spencer Management. One computer code, in particular, called Crystal Ball used Monte Carlo techniques to compute the system cost probability distribution based upon input probability distributions for each cost element. (This code was used in the 1998 and 1999 cost studies.) There were four due diligence cost studies performed under this Cooperative Agreement: $\mathrm{PH}$ 1000 in 1998, PH-1200 in 1999, CHP-250 in 2001 and CHP-160 in 2004. The paragraphs below summarize the results of each cost study.

\section{$\mathrm{PH}-1000$ in 1998}

The $\mathrm{PH}-1000$ design concept consisted of a $740 \mathrm{kWe}$ net $\mathrm{AC}$ pressurized SOFC module with $4608,150 \mathrm{~cm}$ active length, cylindrical cells and a $200 \mathrm{kWe}$ AC gas turbine generator driven by the SOFC module exhaust gas. The calculated electrical efficiency of the combined cycle power system was $60 \%$ (net AC/LHV). The cell power in the $3 \mathrm{~atm}$. SOFC module was $160 \mathrm{~W}$ (net AC cell) compared to $110 \mathrm{~W}$ in an atmospheric unit. The mean forecasted installed system cost for the $\mathrm{PH}-1000$ produced at a volume of 250 units $(1,152,000$ cells) per year was $\$ 1,055 / \mathrm{kWe}$. The mean forecasted cell cost was $\$ 25$ per cell or $\$ 121$ per kWe net AC, module cost excluding cells was $\$ 389$ per $\mathrm{kWe}$, BOP cost was $\$ 425$ per kWe and shipping/installation cost was $\$ 120$ per $\mathrm{kWe}$. These cost estimates assume a fully automated manufacturing facility and a well developed supplier network.

\section{$\mathrm{PH}-1200$ in 1999}

The $\mathrm{PH}-1200$ design concept consisted of a $995 \mathrm{kWe}$ net AC pressurized SOFC module with 5760 cylindrical cells and a $236 \mathrm{kWe}$ AC gas turbine generator. The calculated electrical efficiency of the combined cycle power system was $61.7 \%$ (net AC/LHV). The cell power in the $3.4 \mathrm{~atm}$ SOFC module was $173 \mathrm{~W}$ (net AC cell) compared to $160 \mathrm{~W}$ from the 1998 study. The mean forecasted installed cost to the customer including profit $(\$ 230 / \mathrm{kWe})$ and indirect costs (\$92/kWe) for R\&D, G\&A and S\&M was $\$ 1295$ per kWe under assumptions similar to the 1998 study. Subtracting profit and indirect costs, leaves $\$ 973$ per kWe for the $\mathrm{PH}-1200$ compared to $\$ 1055$ per kWe for the $\mathrm{PH}-1000$ (1998 study).

\section{CHP-250 in 2001}

The CHP-250 due diligence cost study was based upon the OPG CHP-250 that was being designed at the time. The SOFC module contained 2292, $150 \mathrm{~cm}$ active length, cylindrical cells. The cost study deviated from the previous two studies in two ways: 1) the probabilistic cost methodology was not used and 2) cost estimating was performed for the OPG CHP-250 manufactured in the Pilot Manufacturing Facility (2001-2002), a market entry CHP-250 manufactured in a 15 MWe per year facility (2003), and a mature CHP-250 manufactured in a 100 MWe per year facility (2008). Table 9-1 below presents the results of the cost study. The reduction in cell power from $103 \mathrm{~W}$ to $98 \mathrm{~W}$ was due to the electrical efficiency increasing from $46 \%$ to $47 \%$. The increase in cell power to $123 \mathrm{~W}$ in 2008 was due to "future" cell power enhancements not realized at the time. 
Table 9-1 - Summary of CHP-250 Due Diligence Cost Study

\begin{tabular}{|c|c|c|c|}
\hline & $\begin{array}{c}\text { OPG CHP-250 } \\
(2001)\end{array}$ & $\begin{array}{c}\text { Market Entry } \\
\text { CHP-250 } \\
(2003)\end{array}$ & $\begin{array}{c}\text { Mature } \\
\text { CHP-250 } \\
(2008)\end{array}$ \\
\hline $\begin{array}{c}\text { Net AC Power } \\
(\mathrm{kWe} / \text { Eff. }(\%)\end{array}$ & $236 / 46$ & $225 / 47$ & $282 / 49$ \\
\hline $\begin{array}{c}\text { Cell Power } \\
(\text { W net AC) }\end{array}$ & 103 & 98 & 123 \\
\hline $\begin{array}{c}\text { Total installed cost } \\
(\$ 1)\end{array}$ & 31,700 & 2,945 & 1,209 \\
\hline
\end{tabular}

${ }^{(1)}$ Includes profit and indirect costs

CHP-160 in 2004

In 2003, we experienced some cell failures in the OPG CHP-250 unit due to inlet air to fuel space leak, resulting from a non-sealed air inlet plenum design. Subsequently, it was decided to return to sealed air inlet boxes, and a cell stack with half the number of cells. It was also decided to move the air/exhaust recuperator to inside the SOFC module (internal air feed tube recuperator), resulting in the CHP-125. When incorporating cell power enhancements, such as composite interlayer and ScSZ (Section 3.0), the CHP-125 becomes the CHP-160 for the same number of cells (1140).

As in the CHP-250 cost study, the cost estimate assumes a market entry CHP-160 manufactured in a 15 MWe per year manufacturing facility. The total installed cost to the customer, including profit and indirect costs, was estimated to be $\$ 3,236$ per $\mathrm{kWe}$, compared to $\$ 2,945$ per $\mathrm{kWe}$ for the market entry CHP-250. In the case of the CHP-160, learning curve methodology was applied to the market entry costs in order to predict installed system cost as a function of cumulative volume as presented in Figure 9-1. 


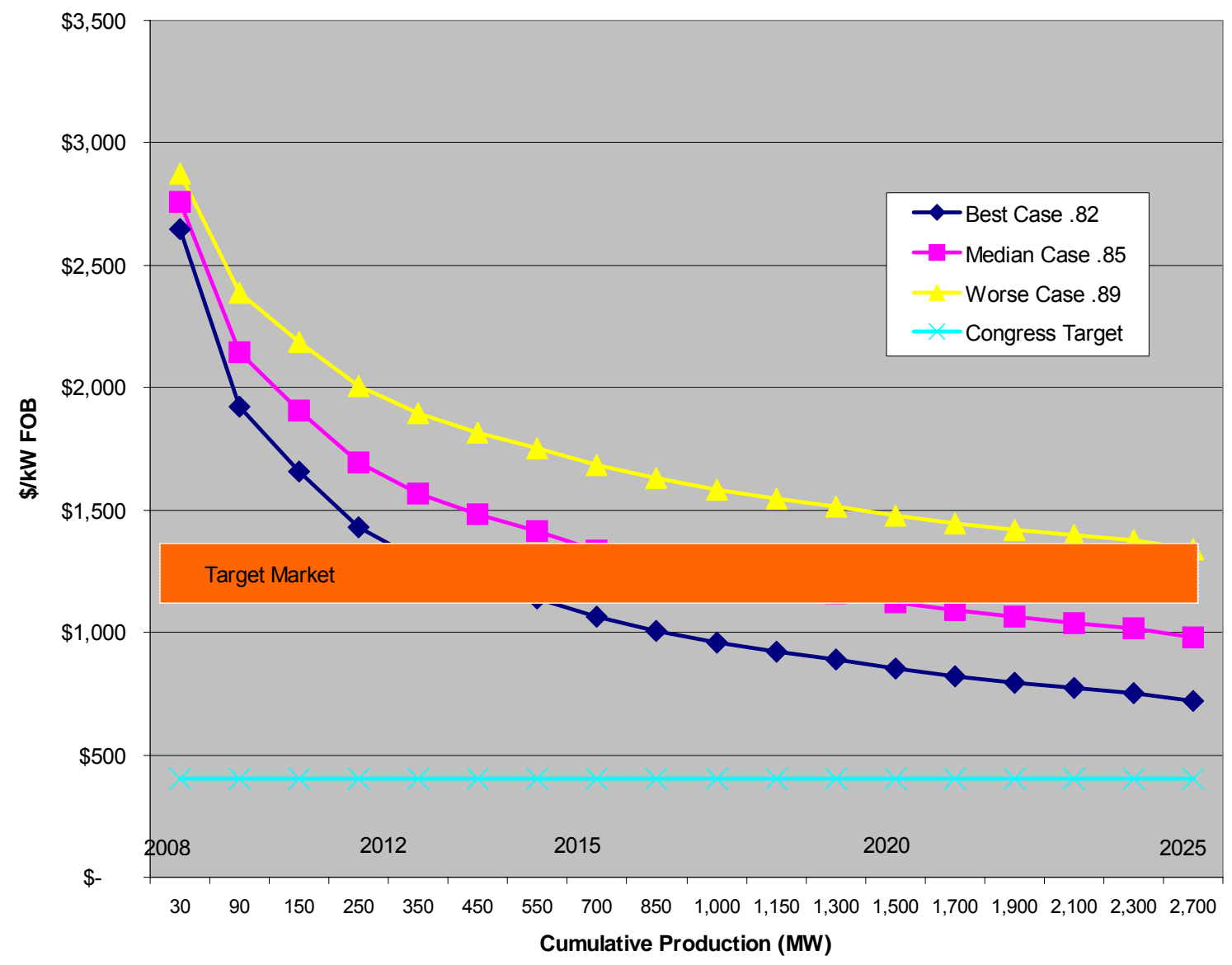

Figure 9-1 - CHP-125 Predicted Power System Cost vs. Cumulative Volume 


\subsection{Summary \& Conclusions}

- Cell manufacturing cost was reduced from $\$ 4,000$ per cell (1997) to $\$ 1000$ per cell (2007) primarily due to the development of 1) in-house air electrode tube making, 2) in-house air electrode powder synthesis, 3) electrolyte and fuel electrode APS, and 4) yield improvement.

- The market entry commercial cost target for the standard cylindrical cell is $<\$ 100$ per cell. Cost studies have projected this target can be achieved in a high volume, automated manufacturing facility.

- The Delta8 cell has great potential to reduce cell cost on a $\$ / \mathrm{kWe}$ basis. Delta8 cell power of $600 \mathrm{~W}$ was achieved at $0.65 \mathrm{~V}$ and $940^{\circ} \mathrm{C}$ compared to $130 \mathrm{~W}$ for the standard cylindrical cell.

- Pressurized module and system technology up to $3.5 \mathrm{~atm}$. absolute has been successfully developed and demonstrated. Pressurized hybrid power systems offer the potential of $60+\%$ electrical efficiency (net AC/LHV) on natural gas.

- Significant progress has been made in reducing module cost by 1) developing and implementing foam top screen bundle technology, 2) developing an alternate supplier of high purity alumina, fiber board, and 3) replacing high temperature alloy parts with alumina parts.

- Net shape casting of ceramic parts offers the highest potential for module cost reduction. This technology development is ongoing.

- External air/exhaust recuperator was moved into the SOFC module for CHP-125, eliminating the metallic recuperator, and high temperature air/exhaust piping. For pressurized hybrid systems the recuperator must be located outside the SOFC module.

- Steam ethanol purge system to replace the very expensive NHMIX system was developed and tested.

- The desulfurizer adsorbent change-out interval has been significantly extended.

- The EDB/ELSAM $100 \mathrm{kWe}$ Combined Heat and Power System (CHP-100) was the most successful of the 5 field unit test programs. The CHP-100 achieved $46 \%$ electrical efficiency, operated for 37,000 hours (33,000 hours for 528 cells), and operated at 3 sites (The Netherlands, Germany and Italy).

- The SCE 220 kWe Pressurized Hybrid Power System (PH-220) was the world's first pressurized SOFC/gas turbine combined cycle system. It successfully demonstrated the viability, and power/efficiency enhancement synergies of integrating the SOFC module with a gas turbine. The PH-220 achieved an electrical efficiency of $52 \%$ and operated for 3,000 hours.

- The OPG CHP-250 and RWE PH-300 both produced the highest power output (193 kWe net AC) of any SOFC power system. Unfortunately, both units had problems with their open air inlet plenum design (inlet air to fuel space leak), which adversely affected stack performance. 
- The Stadtwerke Hannover CHP-125 was the first large field unit to contain all-APS cells and foam top screen bundles as well as the internal air feed tube recuperator. Problems with the pencil type air heaters inside the air feed tubes forced the shutdown of the unit. Design modifications are being implemented and the CHP-125 should be ready for retest in late 2008/early 2009.

- The due diligence cost studies indicate that, under the assumption of a high volume, automated manufacturing facility, commercial cost targets can be met. These cost studies did not consider the Delta8 cell and other innovations being developed for the advanced SOFC module under the SECA Coal-Based Hybrid Program. 


\subsection{Recommendations for Future Work}

- Delta8 and similar type cell configurations offer great cell and module cost reduction potential on a $\$ / \mathrm{kWe}$ basis due to their very high cell power output. The concern is thermal stress induced cell cracking. A comprehensive Delta8 development program focused on manufacturing development, and performance and reliability testing should be executed on a high priority basis.

- Pressurized hybrid systems offer extremely high electrical efficiency potential $(60+\%$ net AC/LHV on natural gas). As projected by the due diligence cost studies, a $1 \mathrm{MWe} P H$ system appears to be cost competitive. Employing Delta8 cells will make this system even more cost competitive. Unfortunately a suitable gas turbine (200-300 kWe for a $1 \mathrm{MWe}$ system, or a 500-750 kWe for a $2.5 \mathrm{MWe}$ system) for modification does not exist, and gas turbine manufacturers are reluctant to invest. So pressurized hybrid technology development needs to be supported on both the module and gas turbine side.

- Atmospheric CHP systems with electrical efficiencies $\geq 45 \%$ on natural gas are also viable commercial systems but the power rating should be $>250 \mathrm{kWe}$ in order to be cost competitive. Such CHP systems with Delta8 cells should be developed as precursors to $\mathrm{PH}$ systems. When the atmospheric technology becomes stabilized and proven, then $\mathrm{PH}$ systems should be developed.

- Net shape casting of ceramic module components should be vigorously pursued.

- The new sealant concept for Delta8 cells, if it works, opens the door for a simplified "zero emissions (ZE)" power system. Once the module technology is stabilized and proven, the ZE concept should be revisited.

- Fuel side heating should be evaluated as an alternative to pencil-type air heaters for CHP modules having an internal, air feed tube recuperator.

- On-cell reformation is potentially an important module cost reduction feature by eliminating SRBs and should be seriously evaluated. 